\title{
High soil solution carbon and nitrogen concentrations in a drained Atlantic bog are reduced to natural levels by 10 years of rewetting
}

\author{
S. Frank ${ }^{1}$, B. Tiemeyer ${ }^{1}$, J. Gelbrecht ${ }^{2}$, and A. Freibauer ${ }^{1}$ \\ ${ }^{1}$ Thünen Institute of Climate-Smart Agriculture Bundesallee 50, 38116 Braunschweig, Germany \\ ${ }^{2}$ Leibniz-Institute of Freshwater Ecology and Inland Fisheries, Central Chemical Laboratory Müggelseedamm 301, 12587 \\ Berlin, Germany
}

Correspondence to: S. Frank (stefan.frank@ti.bund.de)

Received: 29 August 2013 - Published in Biogeosciences Discuss.: 10 October 2013

Revised: 20 February 2014 - Accepted: 11 March 2014 - Published: 25 April 2014

\begin{abstract}
Anthropogenic drainage of peatlands releases additional greenhouse gases to the atmosphere, and dissolved carbon (C) and nutrients to downstream ecosystems. Rewetting drained peatlands offers a possibility to reduce nitrogen (N) and $\mathrm{C}$ losses. In this study, we investigate the impact of drainage and rewetting on the cycling of dissolved $\mathrm{C}$ and $\mathrm{N}$ as well as on dissolved gases, over a period of 1 year and a period of 4 months. We chose four sites within one Atlantic bog complex: a near-natural site, two drained grasslands with different mean groundwater levels and a former peat cutting area rewetted 10 years ago.
\end{abstract}

Our results clearly indicate that long-term drainage has increased the concentrations of dissolved organic carbon (DOC), ammonium, nitrate and dissolved organic nitrogen (DON) compared to the near-natural site. DON and ammonium contributed the most to the total dissolved nitrogen. $\mathrm{Ni}$ trate concentrations below the mean groundwater table were negligible. The concentrations of DOC and N species increased with drainage depth. In the deeply-drained grassland, with a mean annual water table of $45 \mathrm{~cm}$ below surface, DOC concentrations were twice as high as in the partially rewetted grassland with a mean annual water table of $28 \mathrm{~cm}$ below surface. The deeply drained grassland had some of the highestever observed DOC concentrations of $195.8 \pm 77.3 \mathrm{mg} \mathrm{L}^{-1}$ with maximum values of $>400 \mathrm{mg} \mathrm{L}^{-1}$. In general, dissolved organic matter (DOM) at the drained sites was enriched in aromatic moieties and showed a higher degradation status (lower DOC to DON ratio) compared to the nearnatural site. At the drained sites, the $\mathrm{C}$ to $\mathrm{N}$ ratios of the uppermost peat layer were the same as of DOM in the peat profile. This suggests that the uppermost degraded peat layer is the main source of DOM. Nearly constant DOM quality through the profile furthermore indicated that DOM moving downwards through the drained sites remained largely biogeochemically unchanged. Unlike DOM concentration, DOM quality and dissolved $\mathrm{N}$ species distribution were similar in the two grasslands and thus unaffected by the drainage depth.

Methane production during the winter months at the drained sites was limited to the subsoil, which was quasipermanently water saturated. The recovery of the water table in the winter months led to the production of nitrous oxide around mean water table depth at the drained sites.

The rewetted and the near-natural site had comparable DOM quantity and quality (DOC to DON ratio and aromaticity). 10 years after rewetting quasi-pristine biogeochemical conditions have been re-established under continuously water logged conditions in the former peat cut area. Only the elevated dissolved methane and ammonium concentrations reflected the former disturbance by drainage and peat extraction. Rewetting via polder technique seems to be an appropriate way to revitalize peatlands on longer timescales and to improve the water quality of downstream water bodies.

\section{Introduction}

Biogeochemical cycling of carbon $(\mathrm{C})$ and nitrogen $(\mathrm{N})$ in peatlands is determined by the water table position. Under pristine conditions $\mathrm{C}$ and $\mathrm{N}$ fixation exceed gaseous and dissolved losses in these oxygen limited ecosystems (Hemond, 1983; Urban and Eisenreich, 1988; Limpens et al., 2008; 
Blodau, 2002). Thus, peatlands are able to accumulate and store $\mathrm{C}$ and $\mathrm{N}$ over millennia and constitute an important part of the global C and N cycle (Gorham, 1991; Limpens et al., 2006).

In many parts of Europe, peatlands have been drained during the last few centuries for agriculture, forestry and peat extraction. Nowadays, nearly all peatlands in Germany are affected by drainage and mainly used as grassland ,40\%, and arable land, $32 \%$ (Federal Environment Agency, 2013).

The exposure of previously anaerobically stored peat to oxygen is associated with an increase in the $\mathrm{C}$ and $\mathrm{N}$ mineralization (Bridgham et al., 1998), greenhouse gas emissions (Schafer et al., 2012; Flessa et al., 1998; Berglund and Berglund, 2011) and concentrations of water soluble $\mathrm{C}$ and $\mathrm{N}$ (Holden et al., 2004). Therefore, drainage turns these ecosystems from a net $\mathrm{C}$ and $\mathrm{N}$ sink to a source.

Compared to mineral soils, peatlands are characterized by high (20-50 $\mathrm{m} \mathrm{L}^{-1}$ ) dissolved organic carbon (DOC) pore water concentrations (Blodau, 2002). Under pristine conditions, DOC can contribute up to $10 \%$ to overall carbon losses (Limpens et al., 2008). Drainage was shown to increase DOC concentration in peatlands (Wallage et al., 2006; Banas and Gos, 2004; Glatzel et al., 2003; Moore and Clarkson, 2007). Peat degradation under drainage and intensive land use shifts the quality of dissolved organic matter (DOM) towards aged and strongly microbiologically altered DOC (Kalbitz and Geyer, 2002) with a higher amount of aromatic moieties (Hoell et al., 2009; Kalbitz, 2001). The quality of DOM determines its bioavailability (Kalbitz et al., 2003) and its adsorption potential to the mineral phase or iron oxides (Kaiser et al., 1996) and, consequently, DOM turnover and transport to surface waters (Fraser et al., 2001; Stutter et al., 2012).

Peat mineralization after drainage also releases nitrogen in the form of ammonium, nitrate and dissolved organic nitrogen (DON) (Venterink et al., 2002). Ammonium generally increases after drainage whereas nitrification, which is strongly pH dependent (Dancer et al., 1973), is restricted to less acidic peatlands (Holden et al., 2004). The actual export, especially of nitrate from drained peatlands, depends on the flow pathways (Kieckbusch et al., 2006) and denitrification during transport through water saturated, carbonrich layers (van Beek et al., 2004). Especially in drained minerotrophic peatlands, nitrate concentrations in ditches were found to exceed drinking water and general water quality limits (Tiemeyer et al., 2007). High nitrate concentrations pose a strong risk of eutrophication for downstream water bodies.

Rewetting is a common strategy for revitalizing peatlands after peat cutting. Frequently, the main objective of rewetting is for nature conservation by restoring the flora and fauna typical of peatlands. Ideally, successful rewetting creates environmental conditions suitable for peat formation and $\mathrm{C}$ and $\mathrm{N}$ sequestration as well as for improved water quality. Several factors determine whether rewetting leads to quasinatural soil solution concentrations. Firstly, the state of peat degradation determines the mobilizable DOC pool. This pool was found to be highest in degraded peat compared to less degraded peat as a result of a higher amount of redox sensitive substances as well as increased availability of decomposable organic matter (Zak and Gelbrecht, 2007). Secondly, stable high water levels are important to mimic biogeochemical conditions of pristine peatlands as pronounced water table fluctuations throughout the year can boost DOC concentration (Kalbitz et al., 2002). Thirdly, time is an important factor in overcoming the disturbance by drainage. Directly after rewetting, Worrall et al. (2007) measured increased DOC concentrations compared to drained sites. In the long run, Wallage et al. (2006; after up to 4 years) and Hoell et al. (2009; after 20 years) found lower DOC concentrations compared to drained sites.

Rewetting can also reduce dissolved nitrogen losses. This is particularly effective in the case of nitrate as rewetting inhibits nitrification and increases denitrification (Kieckbusch and Schrautzer, 2007). Under water-saturated conditions, the denitrification potential is controlled by the status of the peat degradation, the nitrate load and the temperature (Cabezas et al., 2012). However, high net $\mathrm{N}$ mineralization rates can persist after rewetting (Venterink et al., 2002) and can initially keep ammonium concentrations above natural levels (WindMulder et al., 1996). High nutrient concentrations hamper the revitalization of typical bog vegetation, which usually requires nutrient-poor conditions.

The separate understanding of the cycling of DOC and dissolved $\mathrm{N}$ has improved over last decades, but many studies have either focused on dissolved C or on N. Kalbitz and Geyer (2002) found a different response of DOC and DON to peat degradation and highlighted knowledge gaps about the interaction between DOC and DON in peatlands and about DON in peatlands in general. However, nearly all of the studies on DOC have been conducted in boreal peatlands (Moore, 2003), blanket bogs (Wallage et al., 2006) or fens (Hoell et al., 2009; Kalbitz, 2001), which all differ hydrologically and climatically from raised bogs in the temperate zone. Therefore, it may be questionable whether these findings and the $\mathrm{CO}_{2}$ emission factors for DOC losses summarized in IPCC (2013) are transferable to raised bogs in the temperate zone, especially those under intensive grassland management.

In addition, only very few field studies have simultaneously observed drained, rewetted and natural conditions to determine whether and how fast drainage effects on DOM are reversible and at what risk (Wallage et al., 2006; Glatzel et al., 2003). To fill these knowledge gaps, this study compares the concentrations and qualities of dissolved $\mathrm{C}$ and $\mathrm{N}$ and dissolved gases $\left(\mathrm{CO}_{2}, \mathrm{CH}_{4}\right.$, and $\left.\mathrm{N}_{2} \mathrm{O}\right)$ along the peat profile in a peat bog complex under four land use types: a deep drained intensive grassland, an extensive grassland partially rewetted to shallow water levels for 8 years, a former peat extraction site fully rewetted for 10 years, and a nearnatural bog site. We hypothesize that (1) increased $\mathrm{C}$ and $\mathrm{N}$ mineralization after drainage has increased concentrations of 
Table 1. Plant species and species cover in brackets, water management, and agricultural management of the study sites.

\begin{tabular}{|c|c|c|c|c|}
\hline Site & Plant species cover & Water management & Fertilization & Mowing \\
\hline NN & $\begin{array}{l}\text { Sphagnum fallax H. Klinggr. (86\%) } \\
\text { Eriophorum angustifolium Honck. (10\%) } \\
\text { Myrica gale L. (10\%) } \\
\text { Empetrum nigrum L. }(7 \%) \\
\text { Vaccinium oxycoccos L. }(4 \%) \\
\text { Sphagnum cuspidatum Ehrh. }(4 \%) \\
\text { Rhynchospora alba }(\text { L.) Vahl (3\%) } \\
\text { Drosera rotundifolia L. }(2 \%) \\
\text { Betula pubescens } \text { Ehrh. }(1 \%)\end{array}$ & $\begin{array}{l}\text { None } \\
\text { (possibly influenced by } \\
\text { surrounding drainage) }\end{array}$ & None & None \\
\hline IG & $\begin{array}{l}\text { Poa trivialis L. }(60 \%) \\
\text { Poa pratensis L. }(30 \%) \\
\text { Lolium perenne } \text { L. }(5 \%) \\
\text { Phleum pratense } \text { L. }(3 \%) \\
+ \text { several species with a cover }<1 \%\end{array}$ & $\begin{array}{l}\text { Drainage pipes } \\
\text { Drainage ditches }\end{array}$ & $\begin{array}{l}\text { Cattle slurry } \\
\text { (April, May, } \\
\text { July, } \\
\text { August) }\end{array}$ & $\begin{array}{l}4 \text { times } \\
\text { (May, June, } \\
\text { August, } \\
\text { September) }\end{array}$ \\
\hline EG & $\begin{array}{l}\text { Rhytidiadelphus squarrosus } \\
\text { (Hedw.) Warnst. }(45 \%) \\
\text { Juncus effusus L. }(40 \%) \\
\text { Anthoxanthum odoratum L. }(15 \%) \\
\text { Agrostis stolonifera } \text { L. }(5 \%) \\
\text { Rumex acetosa } \text { L. }(5 \%) \\
\text { Rumex acetosella } \text { L. }(5 \%) \\
+ \text { several species with a cover }<1 \%\end{array}$ & $\begin{array}{l}\text { Drainage ditches (partly } \\
\text { closed since 2003/2004) }\end{array}$ & None & $\begin{array}{l}\text { Once } \\
\text { (August) }\end{array}$ \\
\hline RW & $\begin{array}{l}\text { Sphagnum spp. }(65 \%) \\
\text { Eriophorum vaginatum L. }(55 \%) \\
\text { Molinia caerulea } \text { L. }(12 \%)\end{array}$ & $\begin{array}{l}\text { Polder, } \\
\text { water level regulation } \\
\text { at the outlet } \\
\text { (rewetted since 2002) }\end{array}$ & None & None \\
\hline
\end{tabular}

dissolved $\mathrm{C}$ and $\mathrm{N}$ species in the peat pore water, (2) degradation of the uppermost peat layers at the drained sites has altered the quality of released DOM (DOC to DON ratio and aromaticity) and (3) 10 years of rewetting are too short to reestablish quasi-natural DOM concentrations and quality in the peat pore water.

\section{Materials and methods}

\subsection{Site description}

Our study was conducted in the Ahlen-Falkenberger Moor peat bog complex, which is located $20 \mathrm{~km}$ south of Cuxhaven and the North Sea $\left(53^{\circ} 41^{\prime} \mathrm{N}, 8^{\circ} 49^{\prime} \mathrm{E}\right)$ in north-western Germany. The long-term mean annual temperature and precipitation are $9.4^{\circ} \mathrm{C}$ and $905 \mathrm{~mm}$ (1971-2011; German Weather Service, 2012). The Ahlen-Falkenberger Moor is one of the largest $\left(39 \mathrm{~km}^{2}\right)$ peat bog complexes in northern Germany.

The peatland grew in a depression of Pleistocene sands, partly mixed with gravel and clay. The bog formation started on former fen areas approximately $4000 \mathrm{BC}$ and afterwards directly on Pleistocene sand (Schneekloth, 1970).

Since the Middle Ages, small-scale peat cutting was performed at the edges of the complex. Intense drainage started at the beginning of the 20th century. From 1939 to 1965 over
50 homesteads were established and land use was intensified (Ahrendt, 2012). Nowadays, the Ahlen-Falkenberger Moor peat bog complex is mainly used as grassland. Furthermore, from 1957-2002 industrial peat cutting took place. These areas were rewetted after peat extraction was terminated in 2002. A small area in the south-eastern part of the bog has never been drained (Fig. 1).

Two drained and two wet study sites were chosen to represent the dominant land use forms (Fig. 1): an intensive grassland site (IG), an extensive grassland site (EG), a rewetted peat extraction site (RW) and a near-natural site (NN). The vegetation at IG mainly consists of two species of Poaceae (Table 1). At EG large patches of Juncus effusus L. dominate the vegetation besides mosses and various Poaceae. The vegetation at the wet sites (RW and NN) is composed of typical bog species (Sphagnum spp., Eriophorum spp.). Missing rarer species such as Rhynchospora alba (L.) Vahl or Vaccinium oxycoccos L. as well as the occurrence of Molinia caerulea $\mathrm{L}$. at RW indicates that the transition to an undisturbed bog has not yet been completed.

Agricultural use of the drained sites (IG and EG) has not changed for more than 20 years. IG was cut three-to-five times per year depending on seasonal water table position and trafficability. EG was cut once a year for nature conservation purposes. Mineral fertilizers and cattle slurry were only 


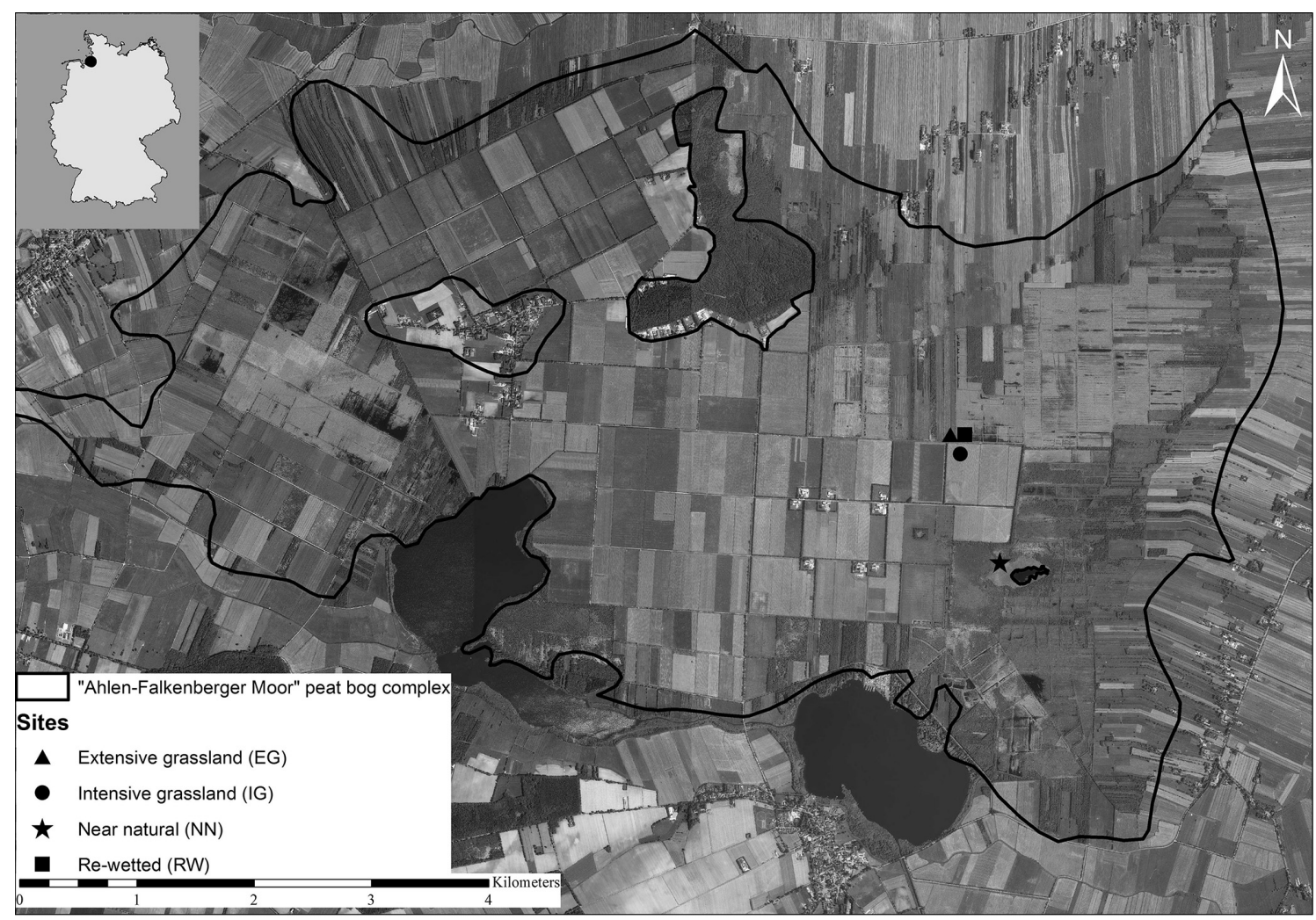

Fig. 1. Location of the study sites within the "Ahlen-Falkenberger Moor" peat bog complex and location of the "Ahlen-Falkenberger Moor" peat bog complex within Germany (upper left) (BKG, 2013).

applied at IG. From 2007-2009 Beetz et al. (2013) reported an average application of $12 \mathrm{~g} \mathrm{~N} \mathrm{~m}^{-2} \mathrm{a}^{-1}$ by mineral fertilizer and $216 \mathrm{~g} \mathrm{C} \mathrm{m}^{-2} \mathrm{a}^{-1}$ by cattle slurry at IG. During our study period, only slurry was applied. In contrast, EG was not fertilized for at least 20 years.

The grassland is divided into rectangular units surrounded by drainage ditches with a depth of at least $1.5 \mathrm{~m}$. To improve drainage and trafficability, PVC drainage pipes were additionally installed at the intensive grassland (drainage depth: $1 \mathrm{~m}$, drainage spacing: $10 \mathrm{~m}$ ). The shallower drainage ditches at EG have partly closed since 2003/2004 due to a lack of ditch maintenance. Thus, the water table at EG is higher than at IG. RW was actively rewetted in 2002 using the polder technique. Dams were constructed around and within the former peat extraction area to create rectangular polder units. Vertically-installed PVC pipes are used as outlets and determine the water table in the polder units. After rewetting, the upper parts of the degraded bog peat $(15-55 \mathrm{~cm})$ started to float and were re-vegetated by Sphagnum spp. RW is now characterized by floating peat layers with a thickness of $65 \mathrm{~cm}$. There is no water management at NN, but the area may be slightly influenced by the neighbouring grassland (Fig. 1).
Prior to our investigations, greenhouse gas emissions were measured from 2007 to 2009 at IG, EG and NN (Beetz et al., 2013).

\subsection{Sampling and chemical analysis}

Samples were taken between February 2012 and February 2013. Dialysis sampler ("peeper"; Hesslein, 1976) were used to sample soil solution in a high vertical resolution. This technique is often used to investigate redox-sensitive solutes in peat pore water (e.g. Zak et al., 2004) and is based on the equilibration of solute concentrations in the soil solution and the deionized water in the peeper chambers, which are covered by a semi-permeable membrane. In our case, the soil solution between 10 and $65 \mathrm{~cm}$ below the surface was sampled. Each plexiglas peeper contained 12 chambers with $5 \mathrm{~cm}$ spacing and a chamber volume of $50 \mathrm{~mL}$ each (Fig. 2). Prior to field installation the chambers were filled with deionized water and covered with a $0.2 \mu \mathrm{m}$ polysulfone membrane filter (HT-Tuffryn 200, Pall Gelman Laboratory). To avoid a disturbance of the natural redox conditions, oxygen from the chamber water needed to be displaced. Therefore, the peepers were placed in PVC vessels filled with deionized water and purged with $\mathrm{N}_{2}$ for two days. The peepers were transported to the field sites in the same PVC vessels. For 


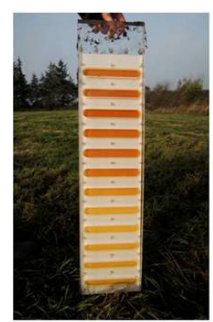

IG

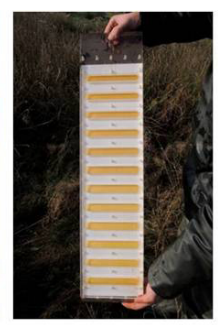

$E G$

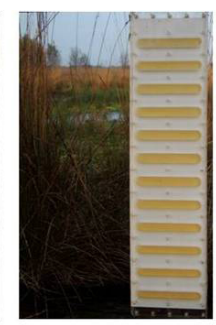

$R W$

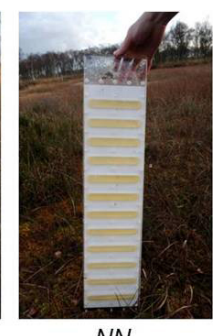

NN
Fig. 2. Pictures of peepers at drained (IG, EG) and wet (RW, NN) sites (sampling date: October 2012).

equilibration with the soil solution, the peepers were left in the field for approximately four weeks, leading to 14 dates of sampling within one year.

Three peepers were installed at each site. Each peeper was inserted into a slit which was cut with a specifically manufactured stainless steel spade. One of the three peepers was used for high resolution vertical profile sampling (each chamber). To account for changing peat properties with depth but to reduce sampling effort and costs, bulk samples (chambers 1-3: $10-22 \mathrm{~cm}$, chambers 3-6: $25-37 \mathrm{~cm}$ and chambers 712: $39-65 \mathrm{~cm}$ ) were collected from the other two peepers. After drawing the peepers from the peat, they were cleaned with deionized water and immediately emptied in the field. Between $10-15 \mathrm{~mL}$ aliquots were filled in PE-vials for the separate measurement of (1) DOC/UV-Vis absorption, (2) major ions and (3) total nitrogen (TN). The samples were cooled during transport. When measurements could not be performed within a few days, samples were stored at $-18^{\circ} \mathrm{C}$ until analysis. No further sample preparation was made.

Between November 2012 and February 2013 (four dates) samples were additionally analysed for dissolved $\mathrm{CO}_{2}, \mathrm{CH}_{4}$ and $\mathrm{N}_{2} \mathrm{O}$. For these analyses $10 \mathrm{ml}$ of solution was inserted into $20 \mathrm{~mL}$ air tight glass vials. The vials were flushed with $\mathrm{N}_{2}$ prior to sampling and prepared with $1 \mathrm{ml} \mathrm{ZnCl}_{2}(50 \%$ w/v) to suppress microbial activity (Romero et al., 1999).

The water table position during the sampling period was recorded using Mini-Divers (Schlumberger Water Services, Delft, Netherlands).

Peat samples were taken with a resolution of $5 \mathrm{~cm}$ using a peat corer and were oven dried $\left(40^{\circ} \mathrm{C}\right)$, sieved and ground prior to measurement. The peat soil organic carbon (SOC) and total nitrogen $\left(\mathrm{N}_{\mathrm{t}}\right)$ content was measured on a LECO TrueMac CN (LECO Corporation, St. Joseph, Michigan, USA). Additionally, a soil profile was dug at each site to determine the soil type and to take samples for the determination of the bulk density (BD).

A DimaTOC 2000 (DIMATEC, Essen, Germany) was used to measure DOC concentration. DOC was calculated as the difference between total carbon (TC; measured via combustion at $850^{\circ} \mathrm{C}$ ) and total inorganic carbon (TIC; measured via combustion at $165^{\circ} \mathrm{C}$ after acidification with $\mathrm{H}_{3} \mathrm{PO}_{4}-$ $40 \% \mathrm{w} / \mathrm{v})$. DOC was measured in at least three replicates.
UV-Vis absorbance was measured on a Shimadzu-1800 spectrophotometer (Shimadzu Germany, Duisburg, Germany) between 200 and $700 \mathrm{~nm}$ in a $1 \mathrm{~cm}$ quartz glass cuvette. The UV-absorbance is often used to assess the quality of DOM. Appropriate wavelengths are shown in Grayson and Holden (2012). In our study, we chose a wavelength of $280 \mathrm{~nm}$, because Chin et al. (1994) reported a strong correlation between SUVA ${ }^{280}$ and aromaticity derived by ${ }^{13} \mathrm{C}-\mathrm{NMR}$ from fulvic acids. SUVA ${ }^{280}$ was calculated as the absorbance at $280 \mathrm{~nm}$ divided by the corresponding DOC concentration and is given in $\mathrm{L} \mathrm{mg}^{-1} \mathrm{~m}^{-1}$. SUVA ${ }^{280}$ was used as DOC quality indicator regarding aromaticity.

Total nitrogen (TN) of the water samples was determined with a Total Nitrogen Analyzer (TN-100; Mitsubishi, Kanagawa, Japan) by reduced pressure chemiluminescence detection. Concentrations of major ions $\left(\mathrm{NH}_{4}^{+}, \mathrm{NO}_{3}^{-}, \mathrm{SO}_{4}^{2-}\right.$ and $\mathrm{Cl}^{-}$) were measured with the 850 Professional ion chromatograph (Metrohm, Filderstadt, Germany). Dissolved organic nitrogen (DON) was calculated as the difference between $\mathrm{TN}$ and the dissolved inorganic nitrogen species $\mathrm{NH}_{4}-\mathrm{N}$ and $\mathrm{NO}_{3}-\mathrm{N}$.

Concentrations of $\mathrm{CO}_{2}, \mathrm{CH}_{4}$ and $\mathrm{N}_{2} \mathrm{O}$ were determined with the 7890-A gas chromatograph (Agilent Technologies, Loveland, USA) using the headspace method. Samples were shaken for $2 \mathrm{~h}$ at $21^{\circ} \mathrm{C}$ prior to measurement to equilibrate headspace and solution. Concentration of dissolved $\mathrm{CO}_{2}$, $\mathrm{CH}_{4}$ and $\mathrm{N}_{2} \mathrm{O}$ were calculated according to Henry's law using the solubilities of $\mathrm{CO}_{2}, \mathrm{CH}_{4}$ and $\mathrm{N}_{2} \mathrm{O}$ at $21^{\circ} \mathrm{C}$ given by Weiss and Price (1980), Weiss (1974) and Wilhelm et al. (1977) and taking into account headspace pressure and volume and the volume of the liquid phase.

Bulked samples were further analysed for $\mathrm{pH}$ and electrical conductivity (WTW, Weilheim, Germany).

As the peeper technique is only applicable under soil moisture conditions near saturation, chambers above the minimum water table were excluded for analysis during each of the 14 sampling periods. Additionally, depth profiles of chloride were used to identify upper chambers with insufficient contact between the membrane and the peat, which were characterized by considerably lower chloride concentrations compared to the mean profile concentrations. The impact of cattle slurry application on dissolved solutes at IG could only be examined in April 2012. These results are discussed separately and the data from this occasion were not included in the general data analysis.

\section{Results and discussion}

\subsection{Peat properties}

At NN the vegetation (Table 1) and peat properties (Table 2) clearly indicate the pristine state of the upper peat layers. Additionally, Beetz et al. (2013) measured ongoing carbon accumulation. Thus, despite the surrounding drainage and 
Table 2. Soil properties $(0-100 \mathrm{~cm})$ of the study sites in the "Ahlen-Falkenberger Moor" peat bog.

\begin{tabular}{|c|c|c|c|c|c|c|}
\hline $\begin{array}{l}\text { Depth } \\
(\mathrm{cm})\end{array}$ & $\begin{array}{l}\text { SOC } \\
(\%)\end{array}$ & $\begin{array}{l}\mathrm{N}_{\mathrm{t}} \\
(\%)\end{array}$ & $\begin{array}{l}\mathrm{C} \text { to } \mathrm{N} \\
\text { ratio }\end{array}$ & $\mathrm{pH}$ & $\begin{array}{l}\mathrm{BD} \\
\left(\mathrm{gcm}^{-3}\right)\end{array}$ & von Post \\
\hline \multicolumn{7}{|c|}{ Near-natural site $(N N)$ : Ombric Fibric Histosol ${ }^{\mathrm{a}}$, peat layer thickness: $440 \mathrm{~cm}$} \\
\hline $0-40$ & 46.7 & 0.9 & 53 & 3.9 & n.d. & 1 \\
\hline $40-50$ & 46.1 & 0.9 & 60 & 4.0 & 0.05 & 1 \\
\hline $50-100^{b}$ & 49.3 & 1.8 & 28 & 5.0 & 0.04 & n.d. \\
\hline \multicolumn{7}{|c|}{ Intensive grassland site $(I G)$ : Ombric Fibric Histosol (Drainic) ${ }^{\mathrm{a}}$, peat layer thickness: $330 \mathrm{~cm}$} \\
\hline $0-12$ & 46.2 & 2.3 & 20 & 5.3 & 0.26 & 10 \\
\hline $12-33$ & 48.9 & 1.2 & 41 & 3.9 & 0.13 & 5 \\
\hline $33-50$ & 49.2 & 0.9 & 54 & 4.1 & 0.12 & 7 \\
\hline $50-100$ & 50.2 & 0.9 & 58 & 4.0 & 0.10 & 3 \\
\hline \multicolumn{7}{|c|}{ Extensive grassland site $(E G)$ : Ombric Fibric Histosol (Drainic) ${ }^{\mathrm{a}}$, peat layer thickness: $340 \mathrm{~cm}$} \\
\hline $0-10$ & 47.3 & 2.4 & 20 & 5.2 & 0.31 & 9 \\
\hline $10-19$ & 49.1 & 1.3 & 40 & 5.0 & 0.12 & 5 \\
\hline $19-50$ & 48.3 & 1.0 & 50 & 4.0 & 0.09 & 3 \\
\hline $50-60$ & 48.0 & 1.0 & 49 & 3.8 & 0.10 & 5 \\
\hline $60-100$ & 49.2 & 0.9 & 54 & 4.0 & 0.07 & 2 \\
\hline \multicolumn{7}{|c|}{ Rewetted site $(R W)$ : Ombric Floatic Hemic Histosola ${ }^{\mathrm{a}}$, peat layer thickness: $260 \mathrm{~cm}$} \\
\hline $0-5$ & 42.7 & 0.9 & 47 & n.d. & n.d. & 1 \\
\hline $5-15$ & 44.2 & 1.0 & 44 & n.d. & n.d. & 2 \\
\hline $15-55$ & 46.5 & 1.2 & 40 & n.d. & n.d. & 6 \\
\hline $55-65^{c}$ & 51.8 & 1.0 & 52 & n.d. & n.d. & 5 \\
\hline
\end{tabular}

n.d. = not determined; $\mathrm{BD}=$ bulk density $\mathrm{SOC}=$ content of soil organic carbon; $\mathrm{N}_{\mathrm{t}}=$ content of total nitrogen; $\mathrm{C}$ to $\mathrm{N}$ ratio $=$ SOC to $N_{t}$ ratio. ${ }^{a}$ IUSS Working Group WRB (2007). ${ }^{b}$ Organic sediment. ${ }^{c} 65-100$ open water body.

increasing land use intensity over the last few decades, the NN site may be used as a near-natural reference site.

The drained sites (IG, EG) are characterized by a strongly degraded amorphous peat layer with high von Post indices and narrowed $\mathrm{C}$ to $\mathrm{N}$ ratios at the soil surface (Table 2). Narrow $\mathrm{C}$ to $\mathrm{N}$ ratios may be caused by the retention of $\mathrm{N}$ in these peat layers, possibly due to the immobilization of $\mathrm{N}$ by microbes during peat decomposition (Wells and Williams, 1996). Despite differences in fertilizer application at EG and IG over the last decades, there is no difference in the $\mathrm{C}$ to $\mathrm{N}$ ratio or other basic peat properties. Basic peat properties clearly indicate peat mineralization, especially in the uppermost layer, which is supported by substantial gaseous $\mathrm{C}$ losses measured by Beetz et al. (2013). Additionally, elevated BD and slightly increased von Post indices at all peat layers compared to NN suggest that peat degradation by compaction and mineralization after drainage has reached deeper peat layers.

The basic peat properties of both the floating degraded peat $(15-55 \mathrm{~cm}$ horizon) and the peat at the bottom of the polder (data not shown) are comparable to the peat layers at drained sites (IG and EG) below the uppermost degraded peat layer. On this peat Sphagnum spp. colonized and built up a $15 \mathrm{~cm}$ thick slightly decomposed peat layer since 2002. The basic properties of this newly formed layer are comparable to NN (Table 2).

\subsection{Water table}

Groundwater table dynamics are shown in Fig. 3. Mean water table positions during the sampling period differed significantly between drained sites (IG: $45 \mathrm{~cm}$, EG: $28 \mathrm{~cm}$ ) and wet sites (RW: $-3 \mathrm{~cm}, \mathrm{NN}:-1 \mathrm{~cm}$ ). Positive values represent a water table below surface and negative values above soil surface. Similarly, the water table fluctuations during the sampling period had higher amplitudes at the drained sites (IG: 5 to $87 \mathrm{~cm}$; EG: 2 to $62 \mathrm{~cm}$ ) than at the wet sites (RW: -27 to $6 \mathrm{~cm}$; NN: -10 to $5 \mathrm{~cm}$ ).

The oscillation of the peat at NN and RW buffered the amplitudes of the water table. Thus, even during dryer summer months, the water tables at these sites did not drop deeper than $6 \mathrm{~cm}$ below soil surface. In contrast, the drainage ditches (open at IG and partly closed at EG) and the active drainage pipes (at IG) led to low mean and minimum water table levels and fast water table fluctuations. Rain events in summer months triggered a strong and fast rise in the water table at IG and EG. This can be explained by the physical properties of drained peat (Silins and Rothwell, 1998). Degraded peat has high bulk densities (Table 2) and thus a lower pore volume 
Table 3. $\mathrm{pH}$-Values, electrical conductivity (EC) and concentration of sulfate $\left(\mathrm{SO}_{4}^{2-}\right)$ and chloride $\left(\mathrm{Cl}^{-}\right)$of the soil solution (means \pm standard deviations).

\begin{tabular}{lllll}
\hline Site & $\mathrm{pH}$ & $\mathrm{EC}\left[\mu \mathrm{Scm}^{-1}\right]$ & $\mathrm{SO}_{4}^{2-}\left[\mathrm{mgL}^{-1}\right]$ & $\mathrm{Cl}^{-}\left[\mathrm{mgL}^{-1}\right]$ \\
\hline$N N$ & $4.0 \pm 0.2$ & $83.2 \pm 15.0$ & $0.8 \pm 0.8$ & $12.7 \pm 1.5$ \\
$I G$ & $4.6 \pm 0.3$ & $204.0 \pm 71.5$ & $16.7 \pm 8.4$ & $19.5 \pm 9.4$ \\
$E G$ & $4.1 \pm 0.2$ & $104.1 \pm 35.3$ & $7.0 \pm 6.2$ & $9.7 \pm 4.0$ \\
$R W$ & $4.1 \pm 0.2$ & $77.9 \pm 11.6$ & $0.5 \pm 0.7$ & $14.0 \pm 2.4$ \\
\hline
\end{tabular}

and a higher share of fine pores. Rain events therefore trigger a stronger rise of the water table per mm of rain (Edom, 2001). Furthermore, the rapid drawdown of the water table after rain-event peaks at IG showed that the drainage system worked efficiently at this site. The daily water table drawdown at IG and EG during periods without precipitation was comparable in summer and winter despite higher transpiration rates of the vegetation in the summer. Drainage management was the most important driver for the water table dynamics at drained sites (IG, EG). Deep water table positions during summer at the drained sites (IG, EG) led to deep oxygen penetration into the soil profile in contrast to the wet sites (RW, NN), which stayed anoxic (see Estop-Aragones et al., 2012).

At the wet sites (RW, NN) all peeper chambers could be sampled throughout the whole sampling period. As mentioned before, pore water from the topsoil at IG and EG could not be sampled under dry conditions. We only used samples below the minimum water table level of each sampling period to ensure that the peeper chamber got sufficient contact with the soil solution during sampling periods. At IG, all peeper chambers could be used on 8 of the 14 sampling dates, chambers below $25 \mathrm{~cm}$ soil depth could be used on 8 of the sampling dates and only chambers below $39 \mathrm{~cm}$ on 9 of the sampling dates. At EG all chambers could be used on 9 of the sampling dates, chambers below $25 \mathrm{~cm}$ on 12 of the sampling dates and chambers below 39 on 12 of the sampling dates. As mentioned earlier 10, 25 and $39 \mathrm{~cm}$ represent the upper boundary of the bulk samples. There is thus a lack of information due to sampling constraints for the upper soil solution of IG and EG during April to September. Differences between drained sites (IG, EG) and wet sites (RW, NN) are mainly driven by differences during moist periods of the investigation period.

\subsection{Basic properties of the soil solution and concentrations of $\mathrm{SO}_{4}^{2-}$ and $\mathrm{Cl}^{-}$}

The soil solution $\mathrm{pH}$ values of around 4 at IG, RW and NN represent the acidic character of bogs (Table 3 ). The slight increase in $\mathrm{pH}$ values at IG may be caused by liming, cattle slurry and fertilizer application over the last few decades.

A low electrical conductivity (EC) as at NN is typical for ombrotrophic peatlands. The EC values at IG and EG were

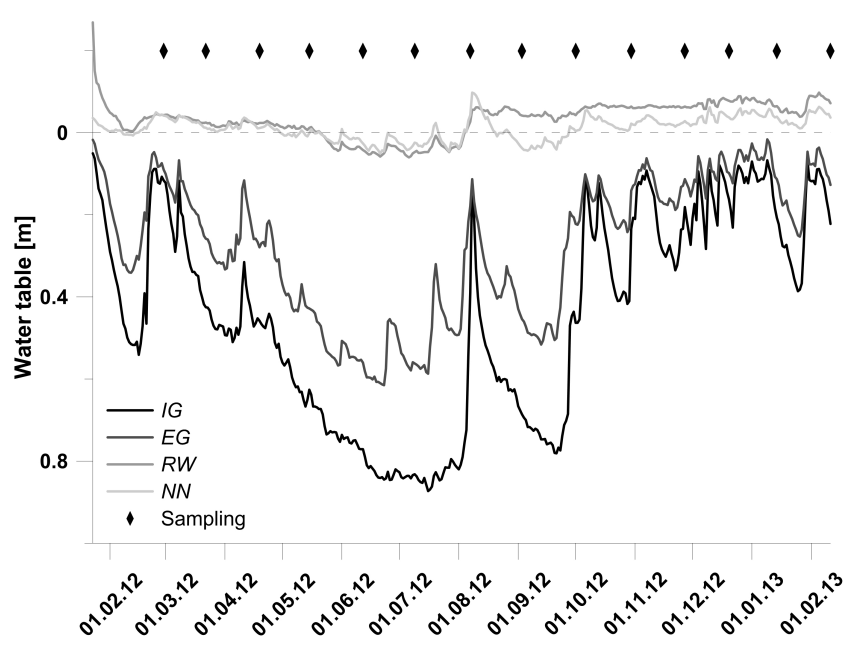

Fig. 3. Groundwater table dynamics at the study sites during the complete sampling period (February 2012-February 2013). The dashed line represents the soil surface.

elevated by $25 \%$ and $145 \%$ compared to $\mathrm{NN}$ due to an increased amount of solutes in the soil solution. This agrees with Wind-Mulder et al. (1996), who found increased EC associated with higher nutrient and $\mathrm{SO}_{4}^{-}$concentrations in post-harvested and natural bogs in Canada. Electrical conductivity at RW was comparable to NN (Table 3), indicating near-natural conditions.

$\mathrm{SO}_{4}^{2-}$ concentrations strongly differed between wet (RW, $\mathrm{NN}$ ) and drained sites (IG, EG). Whereas $\mathrm{SO}_{4}^{2-}$ concentrations were low (usually $<1 \mathrm{mgL}^{-1}$ ) and without a vertical pattern at the wet sites (Fig. 4a), concentrations at drained sites were 21 (IG) and 9 (EG) times higher. $\mathrm{SO}_{4}^{2-}$ concentrations were highest in summer. At IG, $\mathrm{SO}_{4}^{2-}$ concentrations remained relatively high in colder and wetter periods, whereas at $\mathrm{EG}, \mathrm{SO}_{4}^{2-}$ concentrations dropped sharply during winter months. At the drained sites (IG, $\mathrm{EG})$, the topsoil patterns of $\mathrm{SO}_{4}^{2-}$ concentration were partly masked by a lack of summer samples (Fig. 4a). Mean concentrations of $\mathrm{SO}_{4}^{2-}$ tended to decrease below a depth of 40 and $55 \mathrm{~cm}$ at $\mathrm{EG}$ and IG, respectively, where peat layers were mostly water saturated and $\mathrm{SO}_{4}^{2-}$ reducing processes were likely to occur. The vertical and temporal $\mathrm{SO}_{4}^{2-}$ concentration patterns matched the water table dynamics and associ- 

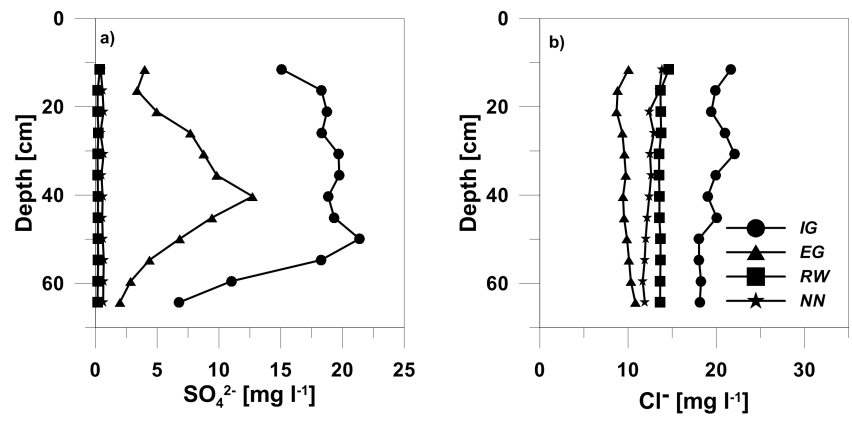

Fig. 4. Vertical profiles of mean (a) sulfate and (b) chloride concentrations at the study sites.

ated oxygen penetration at drained sites, which allowed oxidation of reduced sulfur compounds to $\mathrm{SO}_{4}^{2-}$. In contrast, oxidation was suppressed at wet sites throughout the entire profile.

As mentioned before, $\mathrm{Cl}^{-}$was used to determine whether the peeper chambers got sufficient contact throughout the sampling interval. A vertical pattern was only found at IG (Fig. 4b). The constant depth profiles at our sites are in contrast to measurements by Beer and Blodau (2007) in an oligotrophic bog in Canada, who found a strong increase in the upper $65 \mathrm{~cm}$. This latter profile pattern was mainly explained by diffusion. Thus in our case, different transport mechanisms such as advective transport have to be considered especially at the drained sites.

\subsection{Carbon}

\subsubsection{Dissolved organic carbon - quantities}

Mean DOC concentrations were $195.8 \pm 77.3 \mathrm{mg} \mathrm{L}^{-1}$, $89.4 \pm 31.4 \mathrm{mg} \mathrm{L}^{-1}, \quad 38.8 \pm 6.4 \mathrm{mg} \mathrm{L}^{-1} \quad$ and $48.6 \pm 16.3 \mathrm{mg} \mathrm{L}^{-1}$ at IG, EG, RW and NN, respectively. Mean DOC concentrations at the drained sites were increased by $84 \%$ (EG) and $303 \%$ (IG) compared to NN. At the drained sites DOC concentrations showed a higher spatial and temporal variability than the wet sites (Fig. 5a). Overall, DOC concentrations ranged from 14 to $490 \mathrm{mg} \mathrm{L}^{-1}$. The mean DOC concentrations were negatively correlated with mean annual water table positions. Deep drainage doubled DOC concentrations compared to shallow drainage. The DOC concentrations were fairly constant over depth at EG, NN and RW, but elevated in the upper $35 \mathrm{~cm}$ at IG (Fig. 5b). The vertical pattern at IG suggest that DOC was primarily produced in the uppermost peat layers (McKnight et al., 1985) and was diluted or partly consumed during advective transport to deeper horizons. DOC concentrations at the drained sites (IG, EG) exceeded those of NN in all depths. Near-natural DOC concentrations over the whole profile were found at RW after 10 years of rewetting.

DOC concentrations of the near-natural site $(\mathrm{NN})$ were comparable to previous studies in natural temperate and
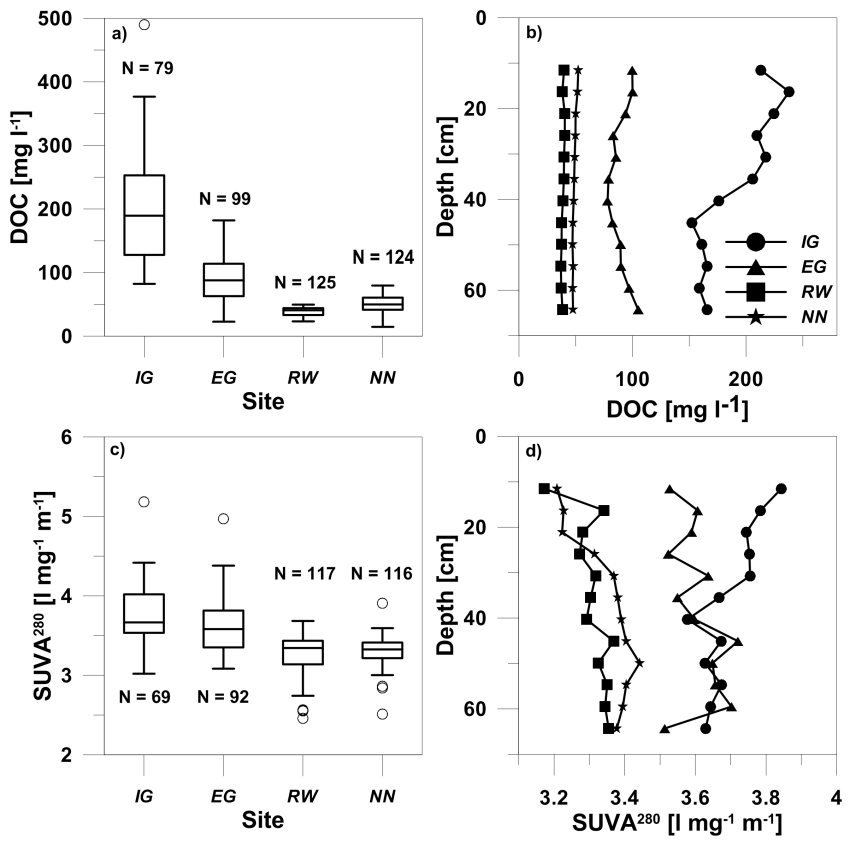

Fig. 5. Left: concentrations of (a) DOC-concentrations and (c) SUVA $^{280}$ at the study sites in the bulk samples (central crossbars represent the median, the boxes-the 75 th and 25 th percentile and the circles-extreme values). Right: vertical profiles of mean (b) DOC concentrations and (d) SUVA 280 values.

boreal peatlands, which often found values of around $50 \mathrm{mg} \mathrm{L}^{-1}$ (Moore, 2003; Blodau et al., 2007), but quite high in comparison to natural blanket peatlands in the UK (e.g. Wallage et al., 2006).

Elevated DOC concentrations $\left(\approx 70 \mathrm{mg} \mathrm{L}^{-1}\right)$ at drained bogs in Poland were reported by Banas and Gos (2004). Their results were comparable to our site EG and rather low compared to our deeply drained, intensively used grassland site (IG). The only study with comparably high DOC concentrations (> $200 \mathrm{mg} \mathrm{L}^{-1}$ ) was also conducted in a German raised bog (Glatzel et al., 2006). In the studies summarized in IPCC (2013), DOC concentrations at drained sites were between 15 and $118 \%$ higher than at natural sites. In contrast, in our temperate raised bog, DOC concentrations were between $84 \%$ (EG) and $303 \%$ (IG) higher at the drained sites than at the reference site NN. This corresponds to the upper end (EG) of, or is by far higher (IG) than, the relative DOC increase given by IPCC (2013). Assuming similar discharge sums after drainage (IG vs. NN), deeply drained, intensively used peatlands in the temperate climate constitute potential large sources of DOC. Most studies summarized in the IPCC (2013) guidelines originate from boreal peatlands, fens or blanked bogs which are all hydrologically and climatically different to raised bogs in temperate Central $\mathrm{Eu}-$ rope. For the latter, the relative DOC concentration increase by drainage given by the IPCC (2013) default might underestimate the dissolved carbon loss. 


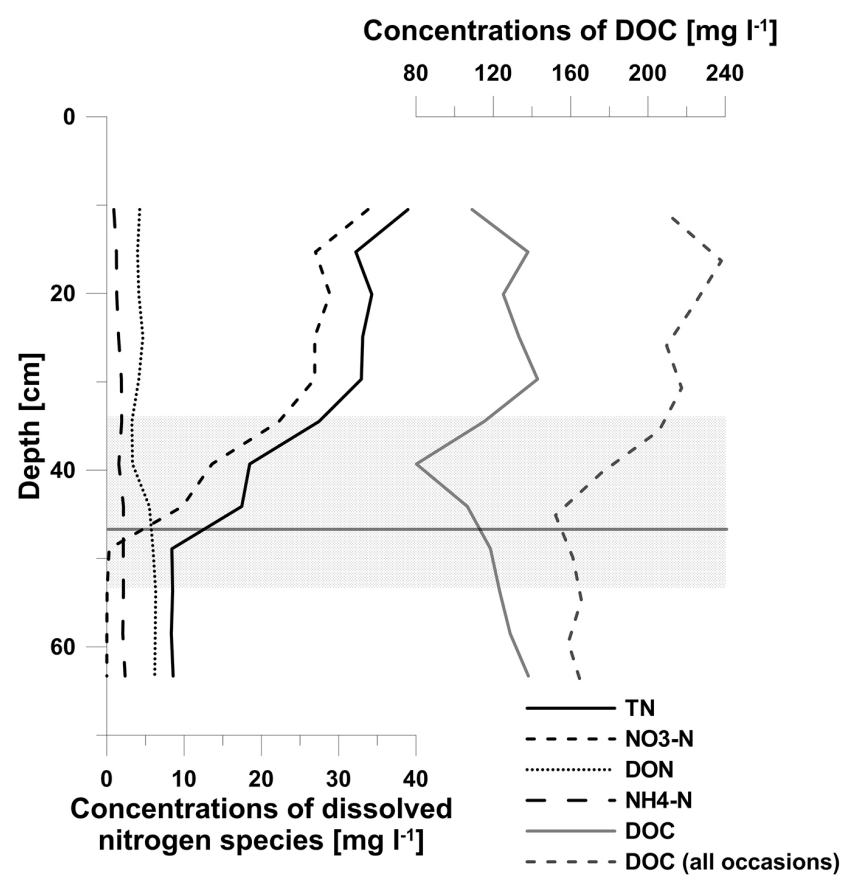

Fig. 6. Vertical profiles of total nitrogen (TN), dissolved organic nitrogen $(\mathrm{DON}), \mathrm{NO}_{3}-\mathrm{N}, \mathrm{NH}_{4}-\mathrm{N}$ and dissolved organic carbon (DOC) concentrations after cattle slurry application in April 2012. DOC (all occasions) represent the mean vertical DOC concentrations during periods without slurry application. The horizontal line represents the mean water table position and the dotted area represents the amplitude of the water table fluctuation during the sampling interval.

The difference in DOC concentrations between IG and the other sites might even have been underestimated in our study due to sampling constraints for the uppermost peat layer at IG during dry summer periods when the highest DOC concentrations are expected.

Several factors (e.g. drainage, fertilizer application, changing plant and microbial communities) can contribute to the high DOC concentrations at the drained grassland sites (IG, EG). Drainage is obviously the most important factor, which determines the length of the period and the volume of peat under aerobic conditions. The enhanced ingress of oxygen during periods of low water tables (Estop-Aragones et al., 2012) increases microbial activity as well as enzymatic activity (Freeman et al., 1996), fostering the degradation of the uppermost peat layer in the short and the long run. This is supported by findings of Clark et al. (2009) who reported an increase of net DOC release during water table drawdown by a factor of 7 during incubation of peat cores at $20^{\circ} \mathrm{C}$. LeiberSauheitl et al. (2014) found a strong linear increase of $\mathrm{CO}_{2}$ emission from organic soils used as grassland with lower water table position. Thus it is likely that the amount of C exposed to oxygen in our case was the most important driver for DOC concentrations differences between IG and EG.
Peat degradation could additionally be primed by a higher amount of and more easily degradable roots and root exudates from Poaceae replacing the original bog vegetation at the drained sites (IG, EG). However, incubation experiments by Basiliko et al. (2012) showed that the addition of root exudates only increased the net $\mathrm{C}$ release by $4 \%$ compared to the microbial respiration in the control plot. The authors stated that the impact of root exudates on peat degradation "priming" seems to be rather small under aerobic conditions. Additionally, aboveground net primary production was relatively similar at IG and EG so it is unlikely that vegetation composition and potential differences in the amount and quality of belowground carbon input can trigger a twofold difference in DOC concentration between IG and EG.

We also ruled out a significant effect of slurry application and past fertilization on DOC concentration. Firstly, we could not measure a direct increase in DOC concentrations after slurry application at IG in April 2012 (Fig. 6). Secondly, the application of $216 \mathrm{~g} \mathrm{C} \mathrm{m}^{-2} \mathrm{a}^{-1}$ by slurry at IG (Beetz et al., 2013) is less than $0.1 \%$ of the SOC stock $\left(53 \mathrm{~kg} \mathrm{C} \mathrm{m}^{-2}\right)$ of the upper $65 \mathrm{~cm}$ of the peat. Thirdly, the peat properties (Table 2) as well as the DOM quality (see Sects. 3.4.2 and 3.6) were nearly identical at both grassland sites although EG did not receive any fertilizer or slurry during the last decades.

Comparable peat properties in IG and EG point to a similar land use history. Prior to drainage ditch closure at EG DOC concentrations may have been as high as at IG. Comparing IG and EG suggests that rewetting a grassland containing a highly degraded peat layer instead of a peat extraction site would also cause a reduction of the DOC concentrations. However, as long as the water table was not restored to the soil surface - a common problem in many rewetting projects - DOC concentrations will likely remain higher than at near-natural sites.

Mean DOC concentrations at RW were comparable to NN 10 years after rewetting. We found constant DOC concentrations over depth at RW even in the more degraded peat layer below $15 \mathrm{~cm}$, which had been aerated during peat harvesting. The mobile DOC pool seems to have been exhausted as suggested by Glatzel et al. (2003) and Wallage et al. (2006) who found lower DOC concentrations in rewetted sites already after 3 to 4 years of rewetting. The re-colonization with typical bog plants may have supported the transition to near-natural C cycling (see Laiho, 2006). Rewetting by polder technique in former peat extraction areas proves to be a suitable method to re-establish permanently anoxic conditions and to reduce $\mathrm{C}$ mineralization and DOC production. Despite differences in land use history (IG, EG vs. RW) comparable peat properties between 15 and $60 \mathrm{~cm}$ (see Sect. 3.1 and Table 2) suggest that the establishment of permanently wet conditions and the removal of the uppermost highly degraded peat layer can reduce DOC concentration to near natural conditions on longer time scales. However, these results are not transferable to all rewetted peatlands, especially nutrient-rich or stronger degraded sites. Overall, we reject our hypothesis and conclude 
that 10 years of full rewetting have been long enough to reestablish near-natural DOC concentrations in a rewetted peat extraction site.

\subsubsection{Dissolved organic carbon - qualities}

Mean SUVA 280 values were elevated by around $10 \%$ at the drained sites (IG: $3.8 \pm 0.4 \mathrm{~L} \mathrm{mg}^{-1} \mathrm{~m}^{-1}$, EG: $3.6 \pm 0.3 \mathrm{~L} \mathrm{mg}^{-1} \mathrm{~m}^{-1}$ ) compared to the wet sites (RW $\left.3.3 \pm 0.3 \mathrm{~L} \mathrm{mg}^{-1} \mathrm{~m}^{-1}, \quad \mathrm{NN}: \quad 3.3 \pm 0.2 \mathrm{~L} \mathrm{mg}^{-1} \mathrm{~m}^{-1}\right)$. SUVA ${ }^{280}$ values ranged from $5.57 \mathrm{~L} \mathrm{mg}^{-1} \mathrm{~m}^{-1}$ to $2.46 \mathrm{~L} \mathrm{mg}^{-1} \mathrm{~m}^{-1}$ (Fig. 5c). Deeper drainage at IG has led to much higher DOC concentrations but no change in DOC quality compared to EG. Within the soil profile, SUVA $^{280}$ values were fairly constant at EG, RW and NN, and slightly elevated in the upper $35 \mathrm{~cm}$ at IG ( Fig. 5d).

These results support our hypothesis that prolonged water table drawdown has led to a higher degree of aromaticity of DOC, which must have been mainly released from the highly degraded, intensely humified upper peat layer (high von Post indices and narrow $\mathrm{C}$ to $\mathrm{N}$ ratio at IG and EG compared to NN). DOC then percolates down the peat profile with only little (IG) or no alteration (EG) in aromaticity. As in our study, Hoell et al. (2009) measured higher SUVA ${ }^{280}$ values in a drained grassland than in a rewetted fen. Kalbitz et al. (1999) as well showed that DOC sampled from degraded peat was enriched in aromatic moieties. The differences in SUVA $^{280}$ between drained sites and wet sites were slightly lower than those found by Kalbitz between fen areas of different land use history. This could be explained by the longer land use history (up to 200 years) and thus even stronger peat degradation compared to our study area (60 years).

The stable SUVA ${ }^{280}$ profiles contrast with the results for mineral soils under grassland where Don and Schulze (2008) found a decline in $\mathrm{SUVA}^{280}$ by around $30 \%$ from 10 to $65 \mathrm{~cm}$ depth. This can be attributed to missing adsorption of aromatic DOC moieties in bog peat, which lacks a mineral phase or iron oxides. Thus, the drainage of bogs with thick peat layers bears a great risk of additional DOC losses of surface waters to the subsurface due to lacking retention capacities.

In contrast to our assumption, the DOC quality of RW and NN was comparable, which supports our findings for DOC concentrations that RW has reached a near-natural DOC status after 10 year of rewetting. Apparently, DOC production and turnover in the soil profile are governed by recent soil redox conditions rather than by the legacy of peat degradation during past drainage reflected in the soil properties of RW below $15 \mathrm{~cm}$.
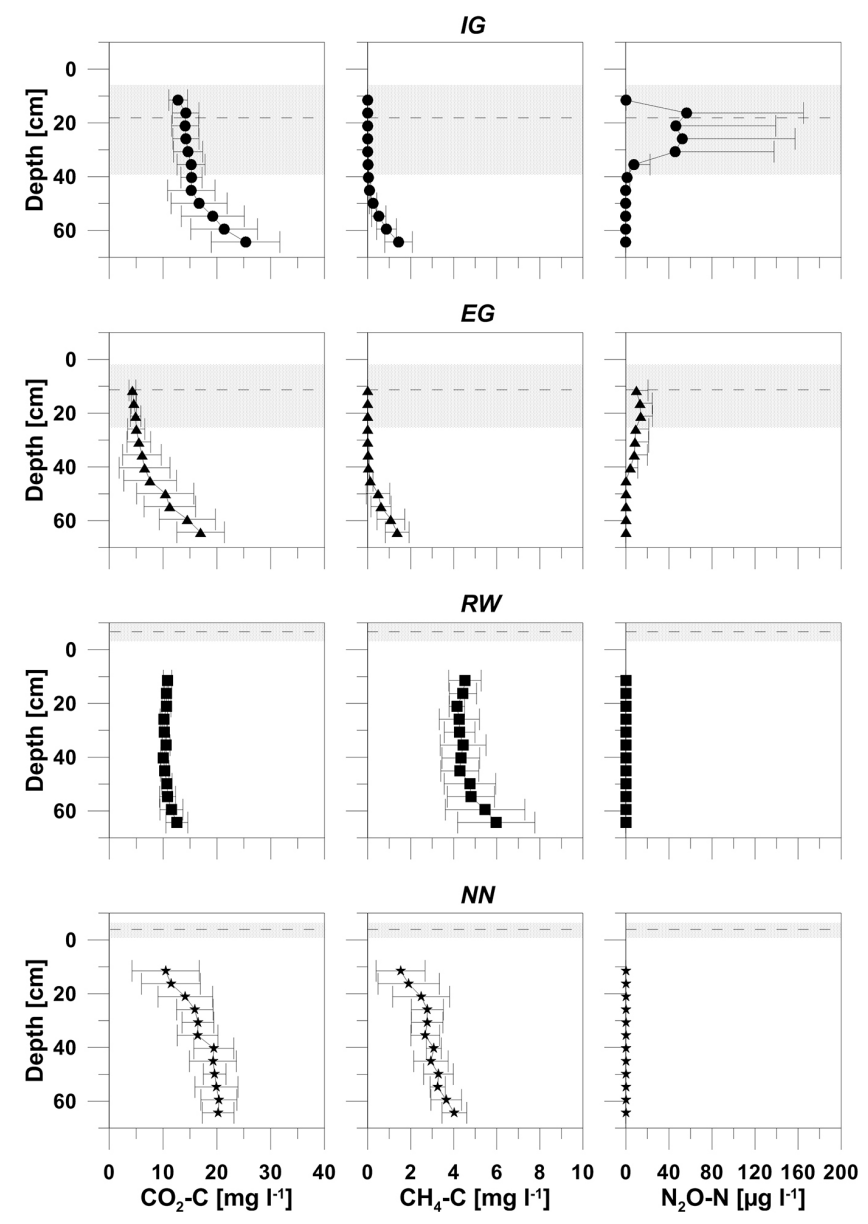

Fig. 7. Concentrations of the dissolved gases $\mathrm{CO}_{2}-\mathrm{C}$ (left), $\mathrm{CH}_{4}-$ $\mathrm{C}$ (centre) and $\mathrm{N}_{2} \mathrm{O}-\mathrm{N}$ (right; mean values per depth and standard deviation). The dashed lines represent the mean water table and the dotted area represents the amplitude of the water table fluctuation during the gas sampling period (November 2012-February 2013).

\subsubsection{Dissolved $\mathrm{CO}_{2}$ and $\mathrm{CH}_{4}$}

Dissolved $\mathrm{CO}_{2}$ was the dominant greenhouse gas during our winter period investigations, but no general difference was found between drained (IG, EG) and wet sites (RW, $\mathrm{NN}$; Fig. 7). The mean concentrations of $\mathrm{CO}_{2}-\mathrm{C}$ decreased from NN, IG, RW to EG: $16.8 \pm 4.4 \mathrm{mg} \mathrm{L}^{-1}, 15.4 \pm 5.0 \mathrm{mg}$ $1^{-1}, 10.4 \pm 1.6 \mathrm{mg} \mathrm{L}^{-1}$ and $7.8 \pm 4.5 \mathrm{mg} \mathrm{L}^{-1}$, respectively. Concentrations of dissolved $\mathrm{CO}_{2}-\mathrm{C}$ tended to increase with depth at all sites.

In contrast, $\mathrm{CH}_{4}-\mathrm{C}$ concentrations at the wet sites (RW: $4.4 \pm 1.3 \mathrm{mg} \mathrm{L}^{-1}$; $\mathrm{NN}: 3.0 \pm 0.9 \mathrm{mg} \mathrm{L}^{-1}$ ) were 11 to 22 times higher than at the drained sites (IG: $0.2 \pm 0.4 \mathrm{mg} \mathrm{L}^{-1}$; EG: $\left.0.3 \pm 0.5 \mathrm{mg} \mathrm{L}^{-1}\right)$. $\mathrm{CH}_{4}-\mathrm{C}$ concentrations tended to increase with depth at all sites. While $\mathrm{CH}_{4}$ was measured over the whole sampling depth at wet sites, it was only found at drained sites in water saturated zones below a depth of $40 \mathrm{~cm}$ (Fig. 7). 

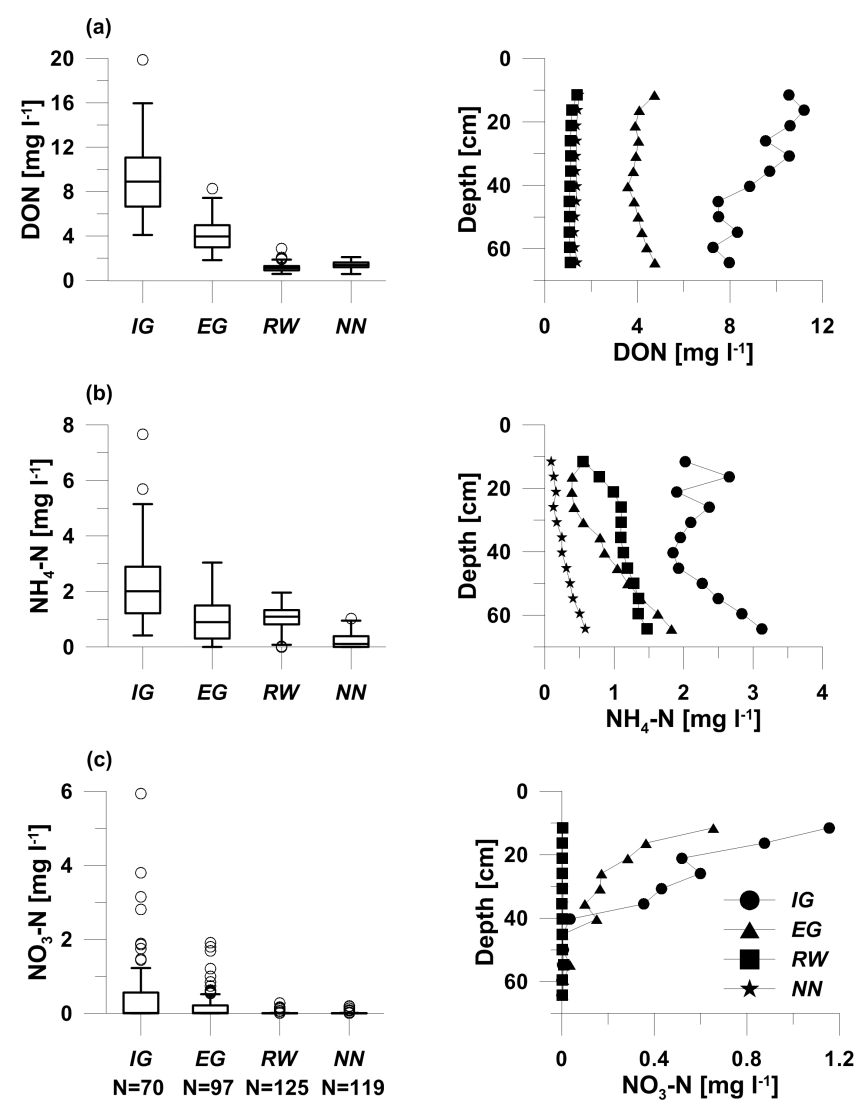

Fig. 8. Left: concentrations of (a) DON, (b) $\mathrm{NH}_{4}-\mathrm{N}$ and (c) $\mathrm{NO}_{3}-\mathrm{N}$ at the study sites in the bulk samples (central crossbars represent the median, the boxes the 75th and 25th percentile and the circles extreme values). Right: vertical profiles of mean concentrations. Sampling date after cattle slurry application excluded (April 2012).

In general, the corresponding DOC concentrations were higher than the concentrations of dissolved $\mathrm{CO}_{2}-\mathrm{C}$ and $\mathrm{CH}_{4}-\mathrm{C}$. Thus, DOC accounts for 74 to $93 \%$ of total dissolved carbon in the peat pore water at our sites.

However, the soil solutions were enriched in dissolved $\mathrm{CH}_{4}-\mathrm{C}$ and $\mathrm{CO}_{2}-\mathrm{C}$ compared to equilibrium water concentration $\left(\mathrm{CO}_{2}-\mathrm{C}\right.$ : $\left.0.33 \mathrm{mg} \mathrm{l}^{-1} ; \mathrm{CH}_{4}-\mathrm{C}: 0.05 \mu \mathrm{g} \mathrm{L}^{-1}\right)$ at atmospheric pressure and at the average air temperature $\left(2{ }^{\circ} \mathrm{C}\right)$ during sampling between November 2012 and February 2013. At supersaturation of the soil solution $\mathrm{CH}_{4}-\mathrm{C}$ and $\mathrm{CO}_{2}-\mathrm{C}$ degas into the atmosphere at the water-air boundary. But $\mathrm{CH}_{4}$ may not necessarily be released from the soil because methanotrophic processes dominate in the upper peat layers. Beetz et al. (2013) did not measure any $\mathrm{CH}_{4}$ emissions in the winter at the drained sites (IG, EG).

An accumulation of microbially produced $\mathrm{CO}_{2}$ and $\mathrm{CH}_{4}$ with depth was also found elsewhere (Clymo and Bryant, 2008; Blodau and Siems, 2012) and was attributed to low diffusion coefficients in water associated with a slow ongoing mineralization in deeper peat layers (Beer and Blodau, 2007).
$\mathrm{CH}_{4}$ production is strictly related to anaerobic conditions. Under anaerobic conditions, methanogens are furthermore outcompeted for electron donors by $\mathrm{NO}_{3}^{-}$, or $\mathrm{SO}_{4}^{2-}$ reducing bacteria. Thus, during reduction of electron acceptors with higher standard redox potential, methanogenesis is fully (e.g. $\mathrm{NO}_{3}^{-}$) or partly (e.g. $\mathrm{SO}_{4}^{2-}$ ) suppressed (Achtnich et al., 1995, Gauci et al., 2004). The absence of oxygen or $\mathrm{NO}_{3}^{-}$and low $\left(<1 \mathrm{mg} \mathrm{L}^{-1}\right) \mathrm{SO}_{4}^{2-}$ concentrations offer suitable conditions for methanogenesis over the whole profile at RW and NN. Elevated net methane production can be expected at $\mathrm{RW}$ compared to $\mathrm{NN}$, because $\mathrm{CH}_{4}-\mathrm{C}$ concentrations exceed those at NN. Temporal water table drawdown in the summer months at the drained sites prohibits methanogenesis during periods of high water tables in the winter months in the seasonally saturated peat layers at IG and EG above a depth of $40 \mathrm{~cm}$ and even below. This agrees with Knorr and Blodau (2009) who observed a delayed onset of methanogenesis in rewetted aerobic peat horizons by up to 50 days as long as other electron acceptors are replenished. Despite the higher water table at EG than at IG, the methane concentrations also suggest that $\mathrm{C}$ cycling is comparable at the two drained sites.

\subsection{Nitrogen}

\subsubsection{Dissolved nitrogen}

TN decreased from IG $\left(11.9 \pm 3.7 \mathrm{mg} \mathrm{L}^{-1}\right)$, to EG $\left(5.2 \pm 1.8 \mathrm{mg} \mathrm{L}^{-1}\right)$, to $\mathrm{RW}\left(2.2 \pm 0.5 \mathrm{mg} \mathrm{L}^{-1}\right)$, to $\mathrm{NN}$ $\left(1.6 \pm 0.4 \mathrm{mg} \mathrm{L}^{-1}\right)$. Overall, TN concentrations ranged from 0.9 to $21.4 \mathrm{mg} \mathrm{L}^{-1}$.

At all sites DON was the dominant nitrogen species (Fig. 8), ranging on average from 55 to $88 \%$ of TN. Mean DON concentrations were $9.2 \pm 3.2,4.1 \pm 1.3,1.2 \pm 0.4$ and $1.4 \pm 0.3 \mathrm{mg} \mathrm{L}^{-1}$ at IG, EG, RW and NN, respectively, and ranged from 0.6 to $19.88 \mathrm{mg} \mathrm{l}^{-1}$. The depth profiles of DON were comparable to DOC and remained nearly constant at EG, RW and NN. At IG, DON values were higher in the top $30 \mathrm{~cm}$ (Fig. 8a).

$\mathrm{NH}_{4}-\mathrm{N}$ was the dominant inorganic $\mathrm{N}$ species, ranging on average from 13 to $46 \%$ of $\mathrm{TN}$. Mean $\mathrm{NH}_{4}$ $\mathrm{N}$ concentration decreased from IG $\left(2.3 \pm 1.4 \mathrm{mg} \mathrm{L}^{-1}\right)$, to RW $\left(1.0 \pm 0.5 \mathrm{mg} \mathrm{L}^{-1}\right)$, to EG $\left(0.9 \pm 0.7 \mathrm{mg} \mathrm{L}^{-1}\right)$, to $\mathrm{NN}$ $\left(0.2 \pm 0.3 \mathrm{mg} \mathrm{L}^{-1}\right)$ and ranged from the detection limit to $9.14 \mathrm{mg} \mathrm{L}^{-1}$. Comparing the concentrations in 10 and $65 \mathrm{~cm}$ depth, $\mathrm{NH}_{4}-\mathrm{N}$ tended to increase at all sites with depth by a factor of 1.5 to 6 (Fig. 8b). At NN and RW the increase was nearly linear. In contrast, the vertical pattern at IG and EG showed the lowest $\mathrm{NH}_{4}-\mathrm{N}$ concentration in upper aerated peat layer and increased linearly at a depth below the mean water table at each site (Fig. 8b).

$\mathrm{NO}_{3}-\mathrm{N}$ was only present at drained sites (IG, EG). At $\mathrm{NN}$ and RW, no or only trace amounts of $\mathrm{NO}_{3}-\mathrm{N}$ could be measured. Average $\mathrm{NO}_{3}-\mathrm{N}$ concentrations were $0.5 \pm 1.0 \mathrm{mg} \mathrm{L}^{-1}$ at IG and $0.2 \pm 0.4 \mathrm{mg} \mathrm{L}^{-1}$ at $\mathrm{EG}$ and ranged from the detection limit to $5.9 \mathrm{mg} \mathrm{L}^{-1}$. The highest 
$\mathrm{NO}_{3}-\mathrm{N}$ concentrations were found at $10 \mathrm{~cm}$ depth and decreased downwards to $40 \mathrm{~cm}$ depth (Fig. 8c). Below $40 \mathrm{~cm}$ depth, no $\mathrm{NO}_{3}-\mathrm{N}$ was detected.

Slurry application at IG in April 2012 led to a spike in nitrogen concentrations in the form of $\mathrm{NO}_{3}-\mathrm{N}$ (Fig. 6). Compared to the colder and wetter periods of the year the $\mathrm{NO}_{3}-\mathrm{N}$ concentrations were increased by a factor of approximately 37 , but only in the soil solution above the mean water table. Surprisingly, concentrations of DON and $\mathrm{NH}_{4}-\mathrm{N}$ were unaffected by the slurry application although considerable amounts of DON and $\mathrm{NH}_{4}-\mathrm{N}$ had been added to the peat surface. The N profile (Fig. 6) can be explained by fast nitrification of applied $\mathrm{N}$ followed by strong denitrification in the soil profile around groundwater level (van Beek et al., 2004) and $\mathrm{N}$ uptake by the vegetation.

In this study, the near-natural site (NN) showed the lowest concentration of all measured $\mathrm{N}$ species, reflecting the nitrogen-poor conditions of pristine bogs. As in our study, Bragazza and Limpens (2004) found DON as the dominant N species in six European bogs. DON concentrations measured during our study were comparable to DON concentrations reported by Moore et al. (2005) for an ombrotrophic bog in Canada. High DON concentrations are typical for peatlands, where anaerobic conditions constrain mineralization of organic nitrogen compounds. Under acidic waterlogged conditions $\mathrm{NH}_{4}-\mathrm{N}$ is the main inorganic $\mathrm{N}$ compound, because nitrification rates are low due to low $\mathrm{pH}$ values and the absence of available oxygen. $\mathrm{NH}_{4}-\mathrm{N}$ concentrations during our study were lower than reported by Hemond (1983) in an ombrotrophic bog in Massachusetts and comparable to ombrotrophic bogs in Canada (Wind-Mulder et al., 1996). Despite low ammonification under water logged conditions, over longer time periods $\mathrm{NH}_{4}-\mathrm{N}$ accumulates in deeper peat layers at NN.

In general, long-term agricultural peatland use associated with drainage has led to increased concentrations of all measured nitrogen compounds (IG, EG vs. NN). The DON concentrations at drained grassland sites were in the range of agricultural fen areas in Germany (Kalbitz and Geyer, 2002), but exceeded concentrations in agriculturally used mineral soils (Siemens and Kaupenjohann, 2002). DON may be further mineralized to $\mathrm{NH}_{4}-\mathrm{N}$ or $\mathrm{NO}_{3}-\mathrm{N}$ in downstream ecosystems. Obviously, drained agricultural bogs bear similar risks of DON export as fens.

Nitrogen species at IG were on average about twice as high as at EG. The DON to $\mathrm{NH}_{4}-\mathrm{N}$ ratio was constantly at 5 to 1 at both sites despite the different fertilization history and was not affected by slurry application. Only $\mathrm{NO}_{3}-\mathrm{N}$ was elevated for a short period immediately after slurry application. This confirms our findings for DOC that fertilization only had a short and reversible impact on dissolved species and drainage depth governs both DOC and $\mathrm{N}$ species concentrations in the soil solution. The carbon to nitrogen ratio in the topsoil of both drained grassland sites (IG, EG) is 20 to 1 so that peat mineralization releases proportional amounts of $\mathrm{N}$ as DON, which is partially ammonified. Plant uptake remains slower than mineralization so that $\mathrm{N}$ species have accumulated in the soil solution. The concentration differences between IG and EG are likely attributed to lower $\mathrm{N}$ mineralization in the wetter EG site but can also result from higher $\mathrm{N}$ use efficiency of the vegetation or more effective nitrification and denitrification. The strong $\mathrm{NO}_{3}-\mathrm{N}$ gradient with depth after fertilization (Fig. 6) and during periods without fertilization (Fig. 8c) additionally indicates a strong denitrification potential at our drained sites. The nitrification potential can be assumed to be lower at our grassland sites compared to a nutrient rich fen area used as grassland in north-eastern Germany, where $\mathrm{NO}_{3}-\mathrm{N}$ was the dominating inorganic $\mathrm{N}$ compound (Tiemeyer et al., 2007).

After 10 year of rewetting, RW showed near-natural (NN) DON concentrations. This agrees with our findings for DOC. In contrast, $\mathrm{NH}_{4}-\mathrm{N}$ concentrations at $\mathrm{RW}$ exceeded those at $\mathrm{NN}$ by a factor of 4.5. Wind-Mulder et al. (1996) also showed that rewetted post-harvested bogs were characterized by elevated $\mathrm{NH}_{4}-\mathrm{N}$ concentrations compared to intact bogs. The $\mathrm{NH}_{4}-\mathrm{N}$ concentrations at $\mathrm{RW}$ doubled from 10 to $25 \mathrm{~cm}$ (Fig. 8b), indicating $\mathrm{NH}_{4}-\mathrm{N}$ uptake or lower $\mathrm{NH}_{4}-\mathrm{N}$ production in the upper newly formed peat layers. Higher $\mathrm{NH}_{4}-\mathrm{N}$ concentrations were especially found in the more strongly degraded peat $(15-65 \mathrm{~cm})$. This agrees with Zak and Gelbrecht (2007) who showed increased $\mathrm{NH}_{4}-\mathrm{N}$ release from degraded peat after rewetting. Thus, it can be assumed that the elevated $\mathrm{NH}_{4}-\mathrm{N}$ concentrations are a memory effect of the former drainage and mineralization of this peat layer during harvesting and prior to rewetting.

\subsubsection{Dissolved $\mathrm{N}_{2} \mathrm{O}$}

$\mathrm{N}_{2} \mathrm{O}$ was only found at the drained sites (IG, EG) and ranged from 0 to $688 \mu \mathrm{g} \mathrm{L}^{-1}$ at IG and 0 to $30 \mu \mathrm{g} \mathrm{L}^{-1}$ at EG. $\mathrm{N}_{2} \mathrm{O}$ concentrations were highest in November and December 2012 in zones of water table fluctuation during the sampling period, in general above $40 \mathrm{~cm}$ depth, where no $\mathrm{CH}_{4}$ was present (Fig. 7).

Due to water table fluctuations saturated and unsaturated conditions alternate in the upper peat layers at IG and EG. These alternations favour nitrification and denitrification and maintain zones of low oxygen content in soil ideal for $\mathrm{N}_{2} \mathrm{O}$ production. Figure 8 clearly indicates nitrate production within the unsaturated zone and strong nitrate consumption in zones of water table fluctuation (10 to $40 \mathrm{~cm}$ ). Both processes produce $\mathrm{N}_{2} \mathrm{O}$ (Wrage et al., 2001) and, indeed, Beetz et al. (2013) measured $\mathrm{N}_{2} \mathrm{O}$ emissions at IG and EG, including the winter periods in 2008 and 2009. The production of $\mathrm{N}_{2} \mathrm{O}$ was restricted to periods directly after the water table rose to the soil surface when nitrate was present. During longer periods of water saturation, $\mathrm{N}_{2} \mathrm{O}$ formation decreased, probably due to ceased nitrification and thus exhaustion of available nitrate or further denitrification to $\mathrm{N}_{2}$. 


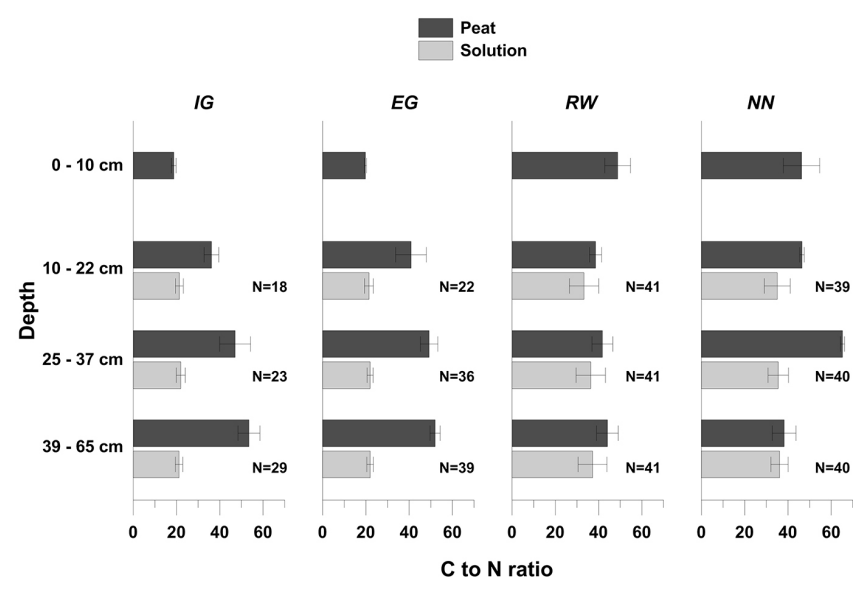

Fig. 9. DOC to DON ratio of the soil solution and $\mathrm{C}$ to $\mathrm{N}$ ratio of the uppermost and the corresponding peat layers $(n=3)$. Bulk solution means of 3 chambers $(10-22 \mathrm{~cm}$ and $25-37 \mathrm{~cm})$ and 6 chambers $(39-65 \mathrm{~cm})$ over the complete sampling period (February 2012February 2013).

\subsection{DOC to DON ratios of soil solution}

The DOC to DON ratios of drained (IG, EG) and wet sites (RW, NN) were clearly different. Drained sites were characterized by narrow and stable DOC to DON ratios (IG: $21.5 \pm 1.9$; EG: $21.9 \pm 1.6$ ) in contrast to the wet sites (RW: $35.4 \pm 7.1$; NN: $35.6 \pm 4.9)$. A low DOC to DON ratio and elevated SUVA ${ }^{280}$ values at IG and EG suggest an increased degradation level of the released DOM (Currie et al., 1996, Austnes et al., 2010). This supports our hypothesis that drainage alters the DOM quality.

At all sites, the DOC to DON ratio remained constant over depth (Fig. 9). Comparing the DOC to DON ratio with the C to $\mathrm{N}$ ratio of peat can help to identify the origin and turnover of DOC within the soil profile. At the wet sites, the DOC to DON ratio was lower than the $\mathrm{C}$ to $\mathrm{N}$ ratio of the peat in the uppermost and in the corresponding peat layer (Fig. 9). At $\mathrm{NN}$, the corresponding $\mathrm{C}$ to $\mathrm{N}$ ratio of the transition zone between peat and limnic organic deposit $(39-65 \mathrm{~cm})$ equals the DOC to DON ratio in soil solution. DOM enriched in $\mathrm{N}$ compared to peat may result from $\mathrm{N}$ immobilization by microbes (Bowden, 1987), microbial N recycling (Broder et al., 2012) of a small N pool (Urban and Eisenreich, 1988) and therefore from an increased input of the microbial biomass. Another possibility may be a predominant release of lowmolecular-weight organic compounds, as indicated by lower SUVA $^{280}$ values (Chin et al., 1994), from the peat to soil solution, which were enriched in N (Qualls and Haines, 1991).

At the drained sites (IG, EG), the DOC to DON ratio of the soil solution equals the $\mathrm{C}$ to $\mathrm{N}$ ratio of the strongly degraded upper peat layer in $0-10 \mathrm{~cm}$ depth (Fig. 9). Michalzik and Matzner (1999) also found concordance in $\mathrm{C}$ to $\mathrm{N}$ ratios of the solid phase and DOM in soil solution from a forest floor. They suggest a predominant release of DOM from the bulk soil organic matter rather than specific sources (e.g. microbial biomass). The similar DOC to DON ratios at IG and EG further suggest that at our sites, fertilizer and slurry application did not alter the DOM composition. This observation contrasts with Kalbitz and Geyer (2002) who attributed a stronger degradation of the uppermost peat layers associated with a shift in DOM quality to intensive use and long-time fertilization. Obviously, the large mineralized peat pool at our site overrides fertilizer as nitrogen source for DOM and mineral $\mathrm{N}$ in the soil solution for most of the year. Furthermore, throughout the profile the DOC to DON ratio remained narrower than the $\mathrm{C}$ to $\mathrm{N}$ ratio of the corresponding peat layers (Fig. 9). This supports our interpretation of the SUVA ${ }^{280}$ values that at the drained sites (IG, EG) DOM is produced in the degraded topsoil during peat degradation and percolates through the profile without microbial alteration. DOM in degraded peatlands is mainly built of recalcitrant humic substances (Zak et al., 2004) which is not readily bioavailable (Kalbitz et al., 2003). When this DOM is exported to ground- and surface waters the downstream photo-oxidation potential is altered as well, because degraded DOM with a higher aromatic content (IG, EG) may be more photo-labile (Köhler et al., 2002) and be converted to $\mathrm{CO}_{2}$ more easily.

\section{Conclusions}

This study is the first to analyse DOM and nitrogen concentrations in the soil solution of long-term drained, rewetted and near-natural peat in a raised bog complex in the temperate climate region. In contrast to other studies, peat degradation and DOM patterns were fully explained by drainage depth but not by contrasting fertilization history of drained bog grasslands. Compared to a near-natural site, artificial drainage of a temperate bog has strongly increased the concentrations of DOC and $\mathrm{N}$ species (DON, $\mathrm{NH}_{4}-\mathrm{N}, \mathrm{NO}_{3}-\mathrm{N}$ ). $\mathrm{DOM}$ and $\mathrm{N}$ quantities strongly raised with the groundwater table depth associated with grassland use intensity. The deeply drained intensive grassland (IG) has a much a higher risk of high DOC and DON losses to downstream water bodies than expected and described so far for other peatland types and climate zones. DOM was mainly released from the aerobic degraded topsoil and percolated through the profile without any clear sign of chemical alteration or physical retention.

After 10 years of rewetting a former peat extraction site, the soil solution has clearly reached quasi-natural conditions (RW vs. NN). The elevated concentration of dissolved methane and $\mathrm{NH}_{4}-\mathrm{N}$ in the degraded peat layer, which had formed the topsoil prior to rewetting, remained the only weak traces of former land use. Restoration by polder technique was successful because permanent anoxic conditions have been re-established in the entire peat profile throughout the year. Partial rewetting also proved a successful step to reduce 
DOM and $\mathrm{N}$ concentrations in the soil solution of managed bog grasslands within less than 10 years.

Acknowledgements. We acknowledge the financial support by the joint research project "Organic soils" funded by the Thünen Institute. The authors are grateful to Jennifer Ehe, Sabine Wathsack, Ute Tambor, Claudia Wiese and Maik Hunziger for laboratory and field support, Michel Bechtold (Thünen Institute) for water table data processing, Dominik Zak (IGB Berlin) for guidance in peeper installation, Wolfram Eschenbach (Thünen Institute) for measuring dissolved gases, Niko Roßkopf (HU Berlin) for soil properties, Stephan Glatzel (Rostock University) for lending us the weather station, Susanne Belting and Stephan Glatzel for vegetation data, and the farmers and the Lower Nature Conservation Authority Cuxhaven for research permissions.

Edited by: T. Laurila

\section{References}

Achtnich, C., Bak, F., and Conrad, R.: Competition for electrondonors among nitrate reducers, ferric iron reducers, sulfate reducers, and methanogens in anoxis paddy soil, Biol. Fert. Soils, 19, 65-72, 1995.

Ahrendt, R.: Die Entdeckung des Ahlenmoores. Aneignung einer Landschaft in der ersten Hälfte des 20. Jahrhunderts, Beiträge zur Geschichte und Kultur des Elbe-Weser-Raumes, Verlag des Landschaftsverbandes der ehemaligen Herzogtümer Bremen und Verden, Stade, 2012.

Austnes, K., Evans, C. D., Eliot-Laize, C., Naden, P. S., and Old, G. H.: Effects of storm events on mobilisation and in-stream processing of dissolved organic matter (DOM) in a welsh peatland catchment, Biogeochemistry, 99, 157-173, 2010.

Banas, K. and Gos, K.: Effect of peat-bog reclamation on the physico-chemical characteristics of the ground water in peat, Pol. J. Ecol., 52, 69-74, 2004.

Beer, J. and Blodau, C.: Transport and thermodynamics constrain belowground carbon turnover in a northern peatland, Geochim. Cosmochim. Ac., 71, 2989-3002, 2007.

Beetz, S., Liebersbach, H., Glatzel, S., Jurasinski, G., Buczko, U., and Höper, H.: Effects of land use intensity on the full greenhouse gas balance in an Atlantic peat bog, Biogeosciences, 10, 1067-1082, 2013, http://www.biogeosciences.net/10/1067/2013/.

Berglund, O. and Berglund, K.: Influence of water table level and soil properties on emissions of greenhouse gases from cultivated peat soil, Soil Biol. Biochem., 43, 923-931, 2011.

Blodau, C.: Carbon cycling in peatlands - a review of processes and controls, Environ. Rev., 10, 111-134, 2002.

Blodau, C. and Siems, M.: Drainage-induced forest growth alters belowground carbon biogeochemistry in the Mer Bleue bog, Canada, Biogeochemistry, 107, 107-123, 2012.

Blodau, C., Roulet, N. T., Heitmann, T., Stewart, H., Beer, J., Lafleur, P., and Moore, T. R.: Belowground carbon turnover in a temperate ombrotrophic bog, Global Biogeochem. Cy., 21, doi:10.1029/2005GB002659, 2007.

Bowden, W. B.: The biogeochemistry of nitrogen in fresh-water wetlands, Biogeochemistry, 4, 313-348, 1987.
Bragazza, L. and Limpens, J.: Dissolved organic nitrogen dominates in European bogs under increasing atmospheric N deposition, Global Biogeochem. Cy., 18, doi:10.1029/2004GB002267, 2004.

Bridgham, S. D., Updegraff, K., and Pastor, J.: Carbon, nitrogen, and phosphorus mineralization in northern wetlands, Ecology, 79, 1545-1561, 1998.

Broder, T., Blodau, C., Biester, H., and Knorr, K. H.: Peat decomposition records in three pristine ombrotrophic bogs in southern Patagonia, Biogeosciences, 9, 1479-1491, 2012,

http://www.biogeosciences.net/9/1479/2012/.

Cabezas, A., Gelbrecht, J., Zwirnmann, E., Barth, M., and Zak, D.: Effects of degree of peat decomposition, loading rate and temperature on dissolved nitrogen turnover in rewetted fens, Soil Biol. Biochem., 48, 182-191, 2012.

Chin, Y. P., Aiken, G., and Oloughlin, E.: Molecular-weight, polydispersity, and spectroscopic properties of aquatic humic substances, Environ Sci Technol, 28, 1853-1858, 1994.

Clark, J. M., Ashley, D., Wagner, M., Chapman, P. J., Lane, S. N., Evans, C. D., and Heathwaite, A. L.: Increased temperature sensitivity of net DOC production from ombrotrophic peat due to water table draw-down, Glob. Change Biol., 15, 794-807, 2009.

Clymo, R. S. and Bryant, C. L.: Diffusion and mass flow of dissolved carbon dioxide, methane, and dissolved organic carbon in a 7-m deep raised peat bog, Geochim. Cosmochim. Ac., 72, 2048-2066, 2008.

Currie, W. S., Aber, J. D., McDowell, W. H., Boone, R. D., and Magill, A. H.: Vertical transport of dissolved organic $\mathrm{C}$ and $\mathrm{N}$ under long-term $\mathrm{N}$ amendments in pine and hardwood forests, Biogeochemistry, 35, 471-505, 1996.

Dancer, W. S., Peterson, L. A., and Chesters, G.: Ammonification and nitrification of $\mathrm{N}$ as influenced by soil $\mathrm{pH}$ and previous $\mathrm{N}$ treatments, Soil Sci. Soc. Am. J., 37, 67-69, 1973.

Don, A. and Schulze, E. D.: Controls on fluxes and export of dissolved organic carbon in grasslands with contrasting soil types, Biogeochemistry, 91, 117-131, 2008.

Edom, F.: Moorlandschaften aus hydrologischer Sicht (chorische Betrachtung), in: Landschaftsökologische Moorkunde, zweite Auflage, edited by: Succow, M. and Joosten, H., Stuttgart, 185228, 2001.

Estop-Aragones, C., Knorr, K. H., and Blodau, C.: Controls on in situ oxygen and dissolved inorganic carbon dynamics in peats of a temperate fen, J. Geophys. Res.-Biogeo., 117, doi:10.1029/2011JG001888, 2012.

Federal Environment Agency: Submission under the United Nations Framework Convention on Climate Change and the Kyoto protocol 2013, National inventory report for the German greenhouse gas inventory 1990-2011, 2013.

Flessa, H., Wild, U., Klemisch, M., and Pfadenhauer, J.: Nitrous oxide and methane fluxes from organic soils under agriculture, Eur. J. Soil Sci., 49, 327-335, 1998.

Fraser, C. J. D., Roulet, N. T., and Moore, T. R.: Hydrology and dissolved organic carbon biogeochemistry in an ombrotrophic bog, Hydrol. Process., 15, 3151-3166, 2001.

Freeman, C., Liska, G., Ostle, N. J., Lock, M. A., Reynolds, B., and Hudson, J.: Microbial activity and enzymic decomposition processes following peatland water table drawdown, Plant. Soil, 180, 121-127, 1996. 
Gauci, V., Matthews, E., Dise, N., Walter, B., Koch, D., Granberg, G., and Vile, M.: Sulfur pollution suppression of the wetland methane source in the 20th and 21st centuries, P Natl Acad Sci USA, 101, 12583-12587, 2004.

Glatzel, S., Kalbitz, K., Dalva, M., and Moore, T.: Dissolved organic matter properties and their relationship to carbon dioxide efflux from restored peat bogs, Geoderma, 113, 397-411, 2003.

Glatzel, S., Lemke, S., and Gerold, G.: Short-term effects of an exceptionally hot and dry summer on decomposition of surface peat in a restored temperate bog, Eur. J. Soil. Biol., 42, 219-229, 2006.

Gorham, E.: Northern peatlands - role in the carbon-cycle and probable responses to climatic warming, Ecol. Appl., 1, 182-195, 1991.

Grayson, R. and Holden, J.: Continuous measurement of spectrophotometric absorbance in peatland streamwater in northern England: Implications for understanding fluvial carbon fluxes, Hydrol. Process., 26, 27-39, 2012.

Hemond, H. F.: The nitrogen budget of Thoreau's bog, Ecology, 64, 99-109, 1983.

Hesslein, R. H.: Insitu sampler for close interval pore water studies, Limnol Oceanogr, 21, 912-914, 1976.

Hoell, B. S., Fiedler, S., Jungkunst, H. F., Kalbitz, K., Freibauer, A., Droesler, M., and Stahr, K.: Characteristics of dissolved organic matter following 20 years of peatland restoration, Sci. Total Environ., 408, 78-83, 2009.

Holden, J., Chapman, P. J., and Labadz, J. C.: Artificial drainage of peatlands: Hydrological and hydrochemical process and wetland restoration, Prog. Phys. Geog., 28, 95-123, 2004.

Intergovernmental Panel on Climate Change (IPCC): 2013 Supplements to the 2006 IPCC Guidelines for national greenhouse gas inventories: Wetlands, 2013.

IUSS Working Group WRB: World reference base for soil resources 2006. Erstes update 2007, Deutsche Ausgabe. Herausgegeben von der Bundesanstalt für Geowissenschaften und Rohstoffe, Hannover, 2007.

Kaiser, K., Guggenberger, G., and Zech, W.: Sorption of DOM and DOM fractions to forest soils, Geoderma, 74, 281-303, 1996.

Kalbitz, K.: Properties of organic matter in soil solution in a German fen area as dependent on land use and depth, Geoderma, 104, 203-214, 2001.

Kalbitz, K. and Geyer, S.: Different effects of peat degradation on dissolved organic carbon and nitrogen, Org. Geochem., 33, 319326, 2002

Kalbitz, K., Geyer, W., and Geyer, S.: Spectroscopic properties of dissolved humic substances - a reflection of land use history in a fen area, Biogeochemistry, 47, 219-238, 1999.

Kalbitz, K., Rupp, H., and Meissner, R.: N-, P- and DOC-dynamics in soil and groundwater after restoration of intensively cultivated fens, Wetlands in Central Europe, 99-116, 2002.

Kalbitz, K., Schmerwitz, J., Schwesig, D., and Matzner, E.: Biodegradation of soil-derived dissolved organic matter as related to its properties, Geoderma, 113, 273-291, 2003.

Kieckbusch, J. and Schrautzer, J.: Nitrogen and phosphorus dynamics of a re-wetted shallow-flooded peatland, Sci. Total Environ., 380, 3-12, 2007.

Kieckbusch, J., Schrautzer, J., and Trepel, M.: Spatial heterogeneity of water pathways in degenerated riverine peatlands, Basic Appl. Ecol., 7, 388-397, 2006.
Knorr, K. H. and Blodau, C.: Impact of experimental drought and rewetting on redox transformations and methanogenesis in mesocosms of a northern fen soil, Soil Biol. Biochem., 41, 1187-1198, 2009.

Köhler, S., Buffam, I., Jonsson, A., and Bishop, K.: Photochemical and microbial processing of stream and soil water dissolved organic matter in a boreal forested catchment in northern Sweden, Aquat. Sci., 64, 269-281, 2002.

Laiho, R.: Decomposition in peatlands: Reconciling seemingly contrasting results on the impact of lowered water levels, Soil Biol. Biochem., 38, 2011-2024, 2006.

Leiber-Sauheitl, K., Fuß, R., Voigt, C., and Freibauer, A.: High $\mathrm{CO}_{2}$ fluxes from grassland on histic Gleysol along soil carbon and drainage gradients, Biogeosciences, 11, 749-761, doi:10.5194/bg-11-749-2014, 2014.

Limpens, J., Heijmans, M., and Berendse, F.: The nitrogen cycle in boreal peatlands, In: Boreal peatland ecosystems, Edited by: Wieder, R. K. and Vitt, D. H., Springer, Berlin, Heidelberg, 2006.

Limpens, J., Berendse, F., Blodau, C., Canadell, J. G., Freeman, C., Holden, J., Roulet, N., Rydin, H., and Schaepman-Strub, G.: Peatlands and the carbon cycle: from local processes to global implications - a synthesis, Biogeosciences, 5, 1475-1491, doi:10.5194/bg-5-1475-2008, 2008.

McKnight, D., Thurman, E. M., Wershaw, R. L., and Hemond, H.: Biogeochemistry of aquatic humic substances in Thoreau's bog, Concord, Massachusetts, Ecology, 66, 1339-1352, 1985.

Michalzik, B. and Matzner, E.: Dynamics of dissolved organic nitrogen and carbon in a Central European Norway spruce ecosystem, Eur. J. Soil Sci., 50, 579-590, 1999.

Moore, T., Blodau, C., Turunen, J., Roulet, N., and Richard, P. J. H.: Patterns of nitrogen and sulfur accumulation and retention in ombrotrophic bogs, Eastern Canada, Glob. Change Biol., 11, 356-367, 2005.

Moore, T. R.: Dissolved organic carbon in a northern boreal landscape, Global Biogeochem. Cy., 17, doi:10.1029/2003GB002050, 2003.

Moore, T. R. and Clarkson, B. R.: Dissolved organic carbon in New Zealand peatlands, New Zeal J. Mar. Fresh., 41, 137-141, 2007.

Qualls, R. G. and Haines, B. L.: Geochemistry of dissolved organic nutrients in water percolating through a forest ecosystem, Soil Sci. Soc. Am. J., 55, 1112-1123, 1991.

Romero, M. C., Gatti, E. M., and Bruno D. E.: Effects of heavy metals on microbial activity of water and sediment communities, World J. Microb. Biot., 15, 179-184, 1999.

Schafer, C. M., Elsgaard, L., Hoffmann, C. C., and Petersen, S. O.: Seasonal methane dynamics in three temperate grasslands on peat, Plant Soil, 357, 339-353, 2012.

Schneekloth, H.: Das Ahlen-Falkenberger Moor - Eine moorgeologische Studie mit Beiträgen zur Altersfrage des Schwarz/Weißtorfkontaktes und zur Stratigraphie des Küstenholozäns, in Geologisches Jahrbuch (Bd. 89), edited by: Dietrich H., Hannover, 63-96, 1970.

Siemens, J. and Kaupenjohann, M.: Contribution of dissolved organic nitrogen to $\mathrm{N}$ leaching from four German agricultural soils, J. Plant. Nutr. Soil Sc., 165, 675-681, 2002.

Silins, U. and Rothwell, R. L.: Forest peatland drainage and subsidence affect soil water retention and transport properties in an Alberta peatland, Soil Sci. Soc. Am. J., 62, 1048-1056, 1998. 
Stutter, M. I., Dunn, S. M., and Lumsdon, D. G.: Dissolved organic carbon dynamics in a UK podzolic moorland catchment: linking storm hydrochemistry, flow path analysis and sorption experiments, Biogeosciences, 9, 2159-2175, doi:10.5194/bg-9-21592012, 2012.

Tiemeyer, B., Frings, J., Kahle, P., Kohne, S., and Lennartz, B.: A comprehensive study of nutrient losses, soil properties and groundwater concentrations in a degraded peatland used as an intensive meadow - implications for re-wetting, J. Hydrol., 345, 80-101, 2007.

Urban, N. R. and Eisenreich, S. J.: Nitrogen cycling in a forested Minnesota bog, Can. J. Bot., 66, 435-449, 1988.

van Beek, C. L., Hummelink, E. W. J., Velthof, G. L., and Oenema, O.: Denitrification rates in relation to groundwater level in a peat soil under grassland, Biol. Fert. Soils, 39, 329-336, 2004.

Venterink, H. O., Davidsson, T. E., Kiehl, K., and Leonardson, L.: Impact of drying and re-wetting on $\mathrm{N}, \mathrm{P}$ and $\mathrm{K}$ dynamics in a wetland soil, Plant. Soil, 243, 119-130, 2002.

Wallage, Z. E., Holden, J., and McDonald, A. T.: Drain blocking: An effective treatment for reducing dissolved organic carbon loss and water discolouration in a drained peatland, Sci. Total Environ., 367, 811-821, 2006.

Weiss, R. F.: Carbon dioxide in water and seawater: The solubility of a non-ideal gas, Mar. Chem., 2, 203-215, 1974.

Weiss, R. F. and Price, B. A.: Nitrous-oxide solubility in water and seawater, Mar. Chem., 8, 347-359, 1980.
Wells, E. D. and Williams, B. L.: Effects of drainage, tilling and PK-fertilization on bulk density, total N, P, K, Ca and Fe and net $\mathrm{N}$-mineralization in two peatland forestry sites in Newfoundland, Canada, Forest Ecol. Manag., 84, 97-108, 1996

Wilhelm, E., Battino, R., and Wilcock, R. J.: Low-pressure solubility of gases in liquid water, Chem. Rev., 77, 219-262, 1977.

Wind-Mulder, H. L., Rochefort, L., and Vitt, D. H.: Water and peat chemistry comparisons of natural and post-harvested peatlands across Canada and their relevance to peatland restoration, Ecol. Eng., 7, 161-181, 1996.

Worrall, F., Armstrong, A., and Holden, J.: Short-term impact of peat drain-blocking on water colour, dissolved organic carbon concentration, and water table depth, J. Hydrol., 337, 315-325, 2007.

Wrage, N., Velthof, G. L., van Beusichem, M. L., and Oenema, O.: Role of nitrifier denitrification in the production of nitrous oxide, Soil Biol. Biochem., 33, 1723-1732, 2001.

Zak, D., Gelbrecht, J., and Steinberg, C. E. W.: Phosphorus retention at the redox interface of peatlands adjacent to surface waters in Northeast Germany, Biogeochemistry, 70, 357-368, 2004.

Zak, D. and Gelbrecht, J.: The mobilisation of phosphorus, organic carbon and ammonium in the initial stage of fen rewetting (a case study from NE Germany), Biogeochemistry, 85, 141-151, 2007. 